\title{
Dios, el hombre y Jesucristo en Cervantes (II)
}

\subsection{El cuerpo y el alma}

En el siglo V antes de Cristo, se produjo una profunda transformación en el pensamiento griego. A partir de Pitágoras y Empédocles, los dos fueron chamanes, se introdujo la creencia en un alma, que es anterior al cuerpo y le sobrevivirá. Se rompió la unidad del ser humano, el equilibrio entre el alma y el cuerpo, y aquélla comenzó a sentirse a disgusto en éste ${ }^{1}$. Con las victorias de Alejandro Magno, las regiones conquistadas se helenizaron. Roma conquistó a Grecia, pero la cultura superior de ésta se impuso sobre la de Roma. "Grecia, conquistada, conquistó a su bárbaro vencedor y trajo las artes al rústico Lacio"2. El dualismo platónico se difundió por todas partes, también en el judaísmo (Filón de Alejandría, Flavio Josefo). Se abrió una sima entre el cuerpo, la carne o el mundo material, y el alma, el espíritu o el mundo inmaterial. Donde mejor se expone este dualismo es en el Fedón platónico. "El cuerpo nos llena de amores, de deseos, de temores, de imágenes de todas clases, de un montón de naderías, de tal manera que, como se dice, por culpa suya no es posible tener nunca un pesamiento sensato" 3 . Hay que dar muerte al cuerpo, mortificarlo, disciplinarlo, separar el alma lo más posible del cuerpo según las tradiciones órficas, acostumbrarla a que se recluya en sí misma y se retire del cuerpo aun en esta vida 4 . Odio al sexo, odio al cuerpo, odio a la mujer, la gran tentadora, odio a todo afecto humano. El interior del hombre se convirtió en un campo de batalla, del alma contra el cuerpo y del cuerpo contra el alma, en una lucha a muerte. Este dualismo platónico está ya pre-

\footnotetext{
1 Cf. DodDS, E. R., Los griegos y lo irracional, Alianza, Madrid 2006, c. 5, p. 137.

2 HORACIO, Epistolas, 1. 2, 1, vv. 156-157.

3 PLATÓn, Fedón 66c.

4 "Alcanzó a conocer esto Sócrates cuando dijo que entonces saldría bienaventurada el ánima de este cuerpo, cuando se hubiese primero ejercitado muy sabia y diligentemente
} 
sente en san Pablo5. Con el tiempo se fue exacerbando dentro del cristianismo. En los Padres del Yermo llegó a extremos increíbles, inhumanos. El alma tenía que triunfar a toda costa sobre el cuerpo, al que había que someter a los más duros castigos: disciplinas, cilicios, vigilias, ayunos, abstinencias, dormir sobre el suelo...

Orígenes llegó a afirmar que, por algún pecado cometido, el alma fue condenada a la cárcel del cuerpo ${ }^{6}$. Mucho antes lo había dicho Filolao: por cierto castigo fue sepultada en la tumba del cuerpo; y otras veces habla de la prisión del cuerpo 7 . Esto no impide que muchos autores que usan estas expresiones defiendan la unión substancial del alma y el cuerpo.

Si el alma está prisionera en la cárcel del cuerpo, todo el mundo interior, sentimientos, pasiones, amores, deseos, placeres, potencias del alma..., se convierte en un hervidero de conflictos, en una manigua confusa y tenebrosa que hay que ir desecando y extirpando de raíz, sometiendo el cuerpo a duros sufrimientos para que el alma quede libre y pueda alzar el vuelo hasta la unión con Dios, como expuso Plotino. Son bien conocidas las purificaciones a las que san Juan de la Cruz somete los sentidos y las potencias del alma hasta que se desprendan de todo afecto humano y se queden en la pura nada para venir a poseerlo Todo. "Mientras que poco a poco / borro de la memoria cuanto impreso / dejó allí el vivir loco / por todo su proceso / vario entre gozo vano y caso avieso. / En ti, casi desnudo / deste corporal velo, y de la asida / costumbre roto el ñudo, / traspasaré la vida / en gozo, en paz, en luz no corrompida"8. Los santos, dice Cervantes, llevaron "vida de ángeles en cuerpos humanos"9; pero él sigue caminos muy distintos a los de los ascetas.

en la muerte, desasiendo el ánima lo más que ser pudiere de la cárcel del cuerpo y de todas sus pasiones para que se halle más exenta y desembarazada de él y así pueda gozar de cosas más altas, y si mucho antes se hubiere también acostumbrado casi a ausentarse del cuerpo por el menosprecio de las cosas corporales y por el amor y contemplación de las espirituales" (ERASMO, El Enquiridion o Manual del caballero cristiano, edición de Dámaso Alonso, prólogo de Marcel Bataillon, CSIC, Madrid 1971, c. 8, regla quinta, pp. 235-236).

5 CRossan, J. D., El nacimiento del cristianismo, Sal Terrae, Santander 2002, pp. XXVI-XXXIII y pp. 36-38. La valoración negativa del cuerpo se expresa claramente en la carta a los Romanos, al que Pablo califica de "cuerpo de pecado" (Rom 6,6), "cuerpo de muerte" (Rom 7,24), "el cuerpo está muerto por el pecado" (Rom 8,10). Por eso le pide a Dios que dé muerte a las "obras del cuerpo" (Rom 8, 13). Con razón dice J. GNILKA: "En cuanto cuerpo, el hombre se halla en el ámbito donde no hay salvación" (cit. por CASTILLO, J. M., Victimas del pecado, Trotta, Madrid 2004, c. 6, p. 166).

${ }^{6}$ Cf. GREEN, Otis H., ib., edic. cit., II, c. 4, 139.

7 Cf. Alonso, D., "Poesía española. Ensayo de métodos y límites estilísticos", en Obras completas, edic. cit., t. IX, p. 145.

${ }^{8}$ LEÓN, fray Luis de, Al apartamiento, en Poesías completas, edic. cit., vv. 26-35, pp. 143-144. Léanse las notas correspondientes.

${ }^{9} Q M, \mathrm{I}, 33,419$. 
Veamos sus textos sobre el dualismo alma y cuerpo. Cuerpo y alma se oponen expresamente en muchos textos. Doy sólo los pasajes de sentido religioso. En las comedias de cautiverio se exalta la fe. El alma, que es libre, es el castillo asediado por los enemigos de la fe cristiana. Los cautivos perderán el cuerpo, pero no el alma, que, libre del cuerpo, levantará su vuelo hacia las altas regiones celestiales.

"Quitando al cuerpo este hierro [la cadena que lleva]/ caeré en otro mayor yerro [pecar contra la castidad], / que el alma fatigue más"10. "Padre del cielo, / si tu luz, si tu mano no me adiestra / a salir de este caos, temo y recelo / que, como el cuerpo está en prisión esquiva, / también el alma ha de quedar cautiva / [invoca a la Virgen]. Si el cuerpo esclavo está, está libre el alma / [...].Yo moriré por lo que al alma toca, / antes que hacer lo que mi alma quiere / [...]. Sólo el que bien muere / puede decir que tiene larga vida, / y el que mal, una muerte sin medida"11. El yugo de la esclavitud del cautivo "bien ves que a cuerpo y alma es peligroso; / y más áquel que tiene presupuesto / de dejarse morir antes que pase / un punto el modo de vivir honesto"12. Un mártir se ve sometido a dos fuegos, al visible que quema su cuerpo y al del amor de Dios: "Al que el cuerpo le abrasaba / o al que el alma le encendía / [...]. Queda el cuerpo en la marina / quemado y apedreado; / el alma el vuelo ha tomado / hacia la región divina"13. "Pues ¿cómo quieres tú, por verte libre / de libertad del cuerpo, echar mil hierros / al alma miserable, desdichada, / cometiendo un pecado tan enorme / como es negar a Cristo y a su Iglesia?"14. Un cadí ordena crucificar a Hazén: "¡Ponedle luego en un palo!", y Hazén contesta: "Mientras yo tuviere aquéste [una cruz de palo], / con quien el alma regalo, / lecho será en que me acueste / el tuyo, Sardanapalo. / Dame, amigo, esa cama, / que es la que el alma más ama, / puesto que [aunque] al cuerpo sea dura"15. A la cruz de Cristo se la llamaba la cama. Así lo he leído en varios textos de san Alonso de Orozco. En el monasterio "no nos debe espantar la clausura", ni la estrechez ni la pobreza, porque todo en él debe representar "a vuestro dulcísimo Esposo Jesucristo pobre, nacido en un pesebre, y pobre muerto con desnudez en la cama estrecha y dura de la santa cruz"16. Y en estos versos de Lope de Vega: "Vuestro Esposo está en la cama, / alma, sien-

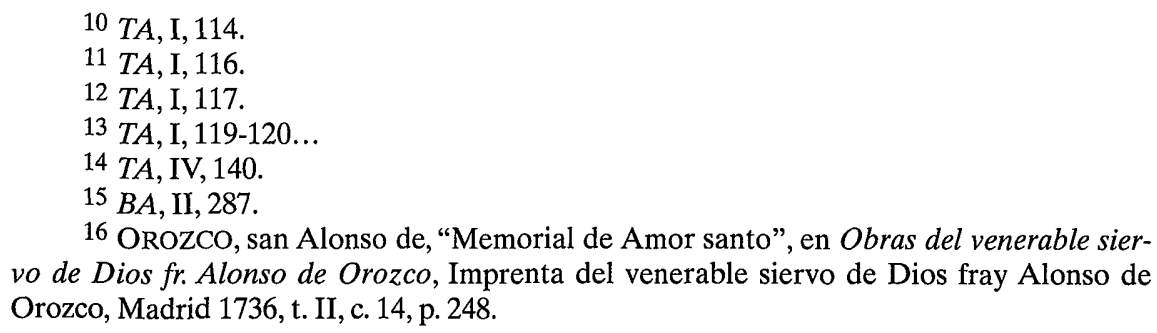

16 OROzCO, san Alonso de, "Memorial de Amor santo", en Obras del venerable siervo de Dios fr. Alonso de Orozco, Imprenta del venerable siervo de Dios fray Alonso de Orozco, Madrid 1736, t. II, c. 14, p. 248. 
do vos la enferma"17. "Nuestros cuerpos en cadenas / y en gran peligro las almas"18. "Y más, si acaso se gana / esta alma, en otra cristiana, / aunque en moro cuerpo mora"19. "No triunfará el inhumano / del alma; del cuerpo, sí, / caduco, frágil y vano [...]. Trájome aquí la beldad, / Señor, que pusiste en mí; / si ella ha de ser instrumento / de perderme, yo consiento, / petición cristiana y cuerda, / que mi belleza se pierda / por milagro en un momento. / [...] Vuélveme fea, Señor; / que no es bien que lleve la palma / de la hermosura del alma / la del cuerpo"20. "Que el alma no es bien peligre, / cuando por fuerza de brazos / echan a su cuerpo lazos / que rendirán a una tigre"21. "Tal confesión me ha de costar la vida, que a trueco de no perder la del alma, daré por bien empleado perder la del cuerpo" 22 .

En el Quijote nos movemos en zonas más templadas, pero se mantiene la oposición. "Si tú tienes ceñido mi cuerpo con tus brazos, yo tengo atada mi alma con mis buenos deseos, que son tan diferentes de los tuyos como lo verás, si con hacerme fuerza quisieres pasar adelante en ellos"23, dice Dorotea a don Fernando. Basilio, que, aparentemente se ha clavado un estoque, pide la mano de Quiteria, pero el cura "le dijo que atendiese a la salud del alma, antes que a los gustos del cuerpo"24; y los amigos de Camacho le pidieron a éste que consintiera que Quiteria le diera la mano de esposa, "porque su alma no se perdiese partiendo desesperado [suicidado] desta vida"25. "Para estar tan herido este mancebo -dijo a este punto Sancho Panza-, mucho habla: háganle que se deje de requiebros, y que atienda a su alma, que, a mi parecer, más la tiene en la lengua que en los dientes" 26 . El cura les dio la bendición y "pidió al cielo diese buen poso [reposo] al alma del nuevo des-

17 Lope de Vega CARpio, F., Al levantarle en la cruz, en Poesías líricas, edición de José F. Montesinos, Espasa-Calpe, Madrid 1963, p. 91.

$18 \mathrm{BA}, \mathrm{II}, 295$.

$19 B A$, II, 297.

20 GS, I, 369-370.

21 GS, II; 380 .

22 AL, 111.

${ }^{23} Q M, 1,28,356$.

${ }^{24} Q M$, II, 21, 877 .

${ }^{25} Q M$, II, 21,878 .

${ }^{26} Q M$, II, 21, 879. "Tener el alma en los dientes" es estar a punto de expirar, escapársele el alma por la boca según se creía. "El alma ha de estar un pie en los labios y el otro en los dientes, si es que hablo con propiedad, y no ha de dejar de esperar su remedio, porque sería agraviar a Dios, que no puede ser agraviado, poniendo tasa y coto a sus infinitas misericordias" (PS, I, 9, 197-198). "No le sabe bien [a Dios], en cuanto creo, la conversión, teniendo el alma a los dientes, cuando el médico no os da más que dos horas de vida" (MALÓN DE CHAIDE, P., La conversión de la Magdalena, edic. cit., t. II, , c. 24, p. 69). En la página anterior, todos rogaban a Quiteria que diese la mano "al pobre Basilio", "porque tenía ya el alma en los dientes". De ahí la reacción de Sancho, al ver lo mucho que hablaba. 
posado"27. El Caballero de la Blanca Luna (Sansón Carrasco) le pone como condición a don Quijote que si le vence tendrá que retirarse durante un año a su aldea, "en paz tranquila y en provechoso sosiego, porque así conviene al aumento de tu hacienda y a la salvación de tu alma"28. El médico aconsejó a Don Quijote "que, por sí o por no, atendiese a la salud de su alma, porque la del cuerpo corría peligro"29. Si Alonso Quijano el bueno, moribundo, declara que el hombre no se ha de burlar con el alma, Sancho el bueno, al partir para el gobierno, nos abre de par en par su interior de hombre de bien y buen cristiano: "Si a vuestra merced le parece que no soy de pro [útil] para este gobierno, desde aquí le suelto, que más quiero un solo negro de la uña [parte mínima] de mi alma, que a todo mi cuerpo"30.

Merlín aconseja a Sancho: "Acabad de dar el sí desta disciplina y creedme que os será de mucho provecho, así para el alma como para el cuerpo: para el alma, por la caridad con que la haréis; para el cuerpo, porque sé que sois de complexión sanguínea, y no os podrá hacer daño sacaros un poco de sangre"31. El temperamento sanguíneo, según la medicina de la época, estaba caracterizado por el humor sangre, el elemento fuego, la cualidad elemental caliente y el órgano corazón, como quedó dicho en el apartado sobre el "alma: creación, destino y naturaleza". A los de complexión sanguínea se les recomendaba sacarse sangre para purificarse de los malos humores. La Duquesa tiene que agradecer su hermosura "primero a Dios y luego, a dos fuentes que tiene en las dos piernas, por donde se desagua todo el mal humor de quien dicen los médicos que está llena"32. "Esto que hasta aquí te he dicho son documentos [enseñanzas] que han de adornar tu alma; escucha ahora los que han de servir para adorno del cuerpo"33

Los moriscos piensan "que en Berbería está el gusto de sus cuerpos y la salvación de sus almas" 34 . El ermitaño Soldino, después de una larga plática, recuerda el lugar común, explícito en algunas reglas monásticas, de que hay que dar sustento al cuerpo y al alma. "Vámonos arriba; daremos sustento a los cuerpos, como aquí abajo lo hemos dado a las almas"35. Hay personajes

${ }^{27} Q M$, II, $21,879$.

${ }^{28} Q M, \mathrm{II}, 64,1265$. Léase la nota a este pasaje.

${ }^{29} Q M$, II, 74, 1329.

$30 \mathrm{QM}, \mathrm{II}, 43,1068$.

$31 \mathrm{QM}, \mathrm{II}, 35,1013$.

${ }^{32} Q M$, II, 48,1115 .

${ }^{33} Q M$, II, 42, 1062.

$34 P S$, III, $11,546$.

$35 P S$, III, 18, 604. En la mesa, escuchad lo que se os leyere según costumbre "para que no sólo la boca reciba el alimento, sino que también los oídos tengan hambre de la palabra de Dios" (San Agustín, Regla 3, 15). 
que deciden perder el cuerpo y el alma. "Ofreceré a los vientos cuerpo y alma / [...]. Al darte de mi alma los despojos"36, dice el suicida Grisóstomo. El que liberó a los galeotes, dice el cura, "quiso hacer un hecho por donde se pierda su alma y no se gane su cuerpo" 37 .

En la oposición belleza del cuerpo / belleza del alma se da la preferencia a la del alma, aunque siempre se requiere que el cuerpo no sea disforme ni monstruoso. Ya hemos visto que La Gran Sultana pide que pierda la belleza del cuerpo para no perder la del alma.

Marcela "hermosa el alma como el cuerpo tiene"38. "Ni imagines que su belleza ni sus tesoros han de ser parte a que yo olvide las minas de tus virtudes y la hermosura incomparable tuya, así del cuerpo como del alma" 39. "La honra y las virtudes son adornos del alma, sin las cuales, el cuerpo, aunque lo sea, no debe de parecer hermoso. Pues si la honestidad es una de las virtudes que al cuerpo y al alma más adornan y hermosean [... $]^{\text {"40 }}$. Dice don Quijote: "Hay dos maneras de hermosura: una del alma y otra del cuerpo; la del alma campea y se muestra en el entendimiento, en la honestidad, en el buen proceder, en la liberalidad y en la buena crianza, y todas estas partes caben y pueden estar en un hombre feo [...]. Yo, Sancho, bien veo que no soy hermoso; pero también conozco que no soy disforme; y bástale a un hombre de bien no ser monstruoso para ser bien querido, como tenga las dotes del alma que te he dicho"41. "El amor que la tenía pasaba del cuerpo al alma"42. Isabela y Sigismunda pierden su belleza corporal durante un tiempo, como una prueba por la que han de pasar sus amantes en el noviciado del amor, pero la recobran antes del matrimonio ${ }^{43}$. La luz neoplatónica no resplandecería si terminasen con un alma hermosa en rostro feo. "Y la belleza del cuerpo muchas veces es indicio de la belleza del alma"44. Es que el alma trabaja en el cuerpo y, al separarse de las cosas perecederas y ser más dueña de sí, lo va transformando en fanal de luz resplandeciente, como bien sabían los frecuentadores de Platón y de los neoplatónicos. "Porque así como la luz encerrada en la lanterna la esclarece y traspasa, y se descubre por ella, así el alma clara y con virtud resplandeciente, por razón de la mucha hermandad que tiene con su cuer-

\footnotetext{
${ }^{36} Q M, \mathrm{I}, 14,164$.

$37 Q M, \mathrm{I}, 29,377$.

$38 Q M, I, 14,163$.

$39 \mathrm{PS}, \mathrm{II}, 7$ (primera parte), 320.

${ }^{40} Q M$, I, 14,168 . Léase la nota a este pasaje.

$41 Q M$, II, 58, 1201.

$42 \mathrm{EI}, 247$.

43 Cf. $E I, 245-253 ;$ PS, IV, 8-10, 676-692.

44 PS, IV, 4, 649.
} 
po, y por estar íntimamente unida con él, le esclarece a él, y le figura y compone cuanto es posible de su misma composición y figura. Así que, si no es virtud del ánimo la limpieza y aseo del cuerpo, es señal de ánimo concertado y limpio y aseado"45. Al contrario, la mucha fealdad era indicio de maldad según el tópico homo deformis et pravus. A medida que avanza el siglo XVII, nos encontramos con un bosque, cada vez más espeso, de mujeres barbudas, hombres deformes, monstruos y enanos.

En el prólogo de las novelas ejemplares, dice Cervantes: "Los requiebros amorosos que en algunas hallarás son tan honestos y tan medidos con la razón y discurso cristiano, que no podrán mover a mal pensamiento al descuidado o cuidadoso que las leyere. Heles dado nombre de ejemplares, y si bien lo miras, no hay ninguna de quien no se pueda sacar algún ejemplo provechoso [...] Donde cada uno pueda llegar a entretenerse, sin daño de barras [sin daño de tercero]: digo sin daño del alma ni del cuerpo, porque los ejercicios honestos y agradables, antes aprovechan que dañan. [...] Una cosa me atreveré a decirte, que si por algún modo alcanzara que la lección destas Novelas pudiera inducir a quien las leyera a algún mal deseo o pensamiento, antes me cortara la mano con que las escribí que sacarlas en público. Mi edad no está ya para burlarse con la otra vida" 46 .

¿Qué quiere decir Cervantes al titularlas Novelas ejemplares? Se ha discutido mucho sobre este prólogo ${ }^{47}$. "Cervantes, que en sus narraciones se ha acercado como nadie antes que él a esa realidad que es la vida humana, presenta en ellas formas de humanidad, ejemplos de lo que es ser hombre o mujer -no olvidemos que tiene las dos formas de vida bien presentes-y la referencia al conjunto de sus novelas o lo que son cada una por sí sola acentúa, si no me equivoco, ese sentido "emergente" y parcial de cada una de las vidas" 48 Dejando a un lado el significado que tenía exemplum en la literatura medie-

45 LEÓN, fray Luis de, La perfecta casada, edic. cit., c. 19, 195. En el pensamiento luisiano, la belleza externa indica belleza moral o psicológica; y al revés, la belleza interna es causa de la belleza externa. Lo interno y lo externo se corresponden mutuamente. Léase la nota del editor. Por eso, cuando habla de la justificación, condena la teoría luterana, que rechaza las mortificaciones externas. El ayuno, el silencio, el no faltar al coro, el cilicio, el andar descalzo sobre el hielo... son buenos como "medicina", "como medio y camino para alcanzar la justicia", "como causas y otras como señales de ánimo concertado" (De los nombres de Cristo, edic. cit., 1..3, Jesús, pp. 639-640). De aquí concluye Bataillon que fray Luis es erasmista (cf. Erasmo y España, edic. cit., c. 14, pp. 765-766) cuando está diciendo exactamente lo contrario de Erasmo.

46 Novelas Ejemplares, prólogo al lector, 18-20.

47 Para el estado de la cuestión, cf. GARCía LóPEZ, J., en CERVANTES, Miguel de, Novelas ejemplares, edic. cit., prólogo de ,pp. XCIII-XCIX.

48 MARÍAS, J., Cervantes, clave española, Alianza, Madrid 1990, c. 10, p. 147; ÍD., Antropología metafísica, edic. cit., c. 11, p. 96. 
val (lo que hay que seguir o lo que hay que evitar) y ateniéndose al que tenía en la tradición retórica a partir de Quintiliano ${ }^{49}$, Javier Blasco ha escrito páginas esclarecedoras sobre la ejemplaridad de las novelas cervantinas. A ellas me remito. No se trata de moralización ni de didactismo. En el prólogo del Quijote lo dice bien claro: "No tiene para qué predicar a ninguno, mezclando lo humano con lo divino, que es un género de mezcla de quien no se ha de vestir ningún cristiano entendimiento" 50 . Cervantes presenta vidas más que ideas, interpretándolas, y esto requiere un nuevo tipo de lector que no confunda la literatura con la vida ni ésta con aquélla; que no traslade a su vida lo que lee en los libros, como le pasó a don Quijote. De los casos referidos en las novelas, el lector vuelve a la realidad lleno de preguntas sobre las ideas del momento ${ }^{51}$.

"Aprovechar y deleitar". Así decía el conocido precepto horaciano: "Los poetas quieren aprovechar o deleitar, o decir a un tiempo cosas que sean agradables y sirvan a la vida"52. El precepto ha sido siempre muy citado en las retóricas, lo repiten muchísimos autores. Cervantes mismo lo reitera en distintas obras. Novelas ejemplares son también los episodios intercalados en el Quijote, mezclando lo provechoso de ellas con el entretenimiento de la acción principal53. Pero Cervantes se inclina más por lo deleitable, por el entretenimiento. No trata de presentar ejemplos y modelos para la vida. En la lectura de la literatura de ficción le interesa más el otium que el negotium. "Sí que no siempre se está en los templos, no siempre se ocupan los oratorios; no siempre se asiste a los negocios, por calificados [importantes] que sean. Horas hay de recreación, donde el afligido espíritu descanse. Para este efecto se plantan las alamedas, se buscan las fuentes, se allanan las cuestas y se cultivan con curiosidad los jardines"54. Lo que hay que pedirles a las obras de ficción es que entretengan y suspendan, que den placer con su lectura, que es también muy provechoso y nutre el alma. "Sólo me falta dar al alma su refacción, como se la daré escuchando el cuento deste buen hombre"55. "Vámonos al espolón a

49 Cf. Lausberg, H., Manual de retórica literaria, Gredos, Madrid 1999, t. I, núms. 410-426.

$50 Q M$, I, prólogo, 18.

51 Cf. Blasco, J., en Cervantes, Miguel de, Novelas ejemplares, edic. cit., estudio preliminar de , pp. XIII-XLIII.

52 HORACIO, Arte poética, vv. 333-334.

53 Cf. NEUSCHÄFER, H.-J., La ética del Quijote. Función de las novelas intercaladas, Gredos, Madrid 1999; CASTRO, A., "La ejemplaridad de las novelas cervantinas", en Hacia Cervantes, edic. cit., 353-374; DUNN, P. N. "Las Novelas ejemplares", en AVALLE-ARCE, J. B. y RILEY, E. C., (eds.), Suma cervantina, Tamesis Books Limited, London1973, pp. 81-118; RILEY, E. C., Teoría de la novela en Cervantes, Taurus, Madrid 1971, pp. 135-146.

$54 N E$, prólogo, 18. Cf. $Q M, \mathrm{I}, 32,409 ; \mathrm{I}, 48,609$.

$55 Q M, I, 50,630$. 
recrear los ojos del cuerpo, pues ya hemos recreado los del entendimiento"56 escuchando el Coloquio de los perros.

"Honestas y agradables". Se acusaba a la literatura de entretenimiento de incitar a la lujuria, muy especialmente a la mujer ${ }^{57}$, que, como habían dicho Aristóteles y santo Tomás, era "animal imperfecto"58, mas dimidiatus, y apetecía al varón como la materia a la forma ${ }^{59}$. El Concilio de Trento prohibió en absoluto los libros que "tratan de materias lascivas u obscenas, las narran o enseñan"60. Pero en esta materia los erasmistas no le iban a la zaga. ¿Responde el prólogo a las convicciones de Cervantes o es un prólogo exculpatorio y protector, un prólogo galeato, frente a las autoridades eclesiásticas y la Inquisición?¿Quién podrá deslindar lo que pasa en el interior de las personas? Las palabras de Cervantes son demasiados graves e insisten en la castidad, lo hace también en otras obras, como para que se le pueda tachar de "hábil hipócrita", como lo hicieron Ortega y Gasset y Américo Castro. "Sería una falsa conclusión pensar que el hecho de que Cervantes se aparte de sus principios es incompatible con su creencia en esos principios. Por el contrario, ambas actitudes suelen ir unidas con bastante frecuencia. Los deslices que hallamos en sus novelas no constituyen violaciones muy espectaculares de las reglas. [...] Tampoco deben exagerarse desde el punto de vista moral. Sus propias protestas de moralidad han atraído mayor atención hacia esos deslices que la que éstos habrían atraído por sí mismos. Considerando su obra en conjunto, Cervantes es uno de los escritores más profundamente morales"61. Por otra parte, en sus últimos años se acentuó su fervor religioso. Entró en la Congregación de Esclavos del Santísimo Sacramento (1609) y en la Orden Tercera de san Francisco (1616). Al publicar las Novelas ejemplares (1613), excluyó La tía fingida e hizo una nueva redacción de El celoso extremeño, en la que desaparece el adulterio de los protagonistas, aunque se mantiene el ambiente cargado de sexualidad. Mantuvo, sin embargo, en su integridad $E l$ viejo celoso, donde triunfa el instinto sexual, al publicar los Entremeses (1615)62.

\footnotetext{
${ }^{56} \mathrm{CP}, 623$. Espolón, 'plaza y paseo de Valladolid, sobre el Pisuerga'.

57 Cf. VEGA, J., "Tres apologistas de la "lengua vulgar": san Alonso de Orozco, fray Luis de León y fray Pedro Malón de Chaide", en Religión y Cultura, 48 (2002), pp. 272-274. 297-300. 309-316. 325-328.

${ }^{58} Q M, 1,33,421$.

59 Cf. ROJAS ,F. de, ( y "antiguo autor"), La Celestina, Crítica, Barcelona 2000, primer auto, p. 46.

60 DenZINGER-SCHÖNMETZER, Enchiridion Symbolorum, Herder, Barcinone $1973^{35}, \mathrm{n}^{\circ} .1857$.

61 RILEY, E. C., Teoría de la novela en Cervantes, edic. cit., c. 3, p. 156.

${ }^{62}$ Cf. LAPESA, R., "En torno a La española inglesa y el Persiles", en De la Edad Media a nuestros dias, Gredos, Madrid 1967, pp. 250-252.
} 
Leo Spitzer introdujo el perspectivismo en los estudios sobre el Quijote. Los personajes no dicen más que sus verdades y el lector es libre de tomarlas o no en consideración, pero el mismo Spitzer advierte que, cuando Cervantes habla de cuestiones éticas, no todo es relativo ni subjetivo. En moral, Cervantes no es perspectivista ni ambiguo ${ }^{63}$. Cervantes se mueve dentro de la moral cristiana, pero no de una moral dogmática, fundamentalista, abstracta, que no tiene en cuenta a las personas. Parte siempre de la libertad del índividuo -"yo nací libre"64, dice Marcela; "libre nací, y en libertad me fundo"65, dice Gelasia (las mujeres afirman su libertad frente al acoso de los hombres. Las hacas galicianas responderán a lo bestia frente al acoso de Rocinante ${ }^{66}$ )-; pero reconoce, a la vez, las limitaciones de la libertad. En la moral, hay que tener en cuenta "la depravada y flaca naturaleza humana". Dejarse llevar únicamente por la libertad es "locura", "desatino", "engaño" (son palabras usadas por él), estar fuera de razón, sobre todo cuando intervienen dos pecados capitales, la soberbia y la lujuria. "Mira que el que busca lo imposible, es justo que lo posible se le niegue" 67 . En la realidad hay siempre un margen de perfeccionamiento y éste es el que hay que descubrir y realizar. No se puede imponer una verdad absoluta y eterna, utópica y ucrónica, que es la verdad creada desde "ningún sitio" y desde "ningún tiempo"68. Porque esa que llaman verdad absoluta fue creada en un tiempo y en un lugar determinados. Hay que respetar la libertad de los demás, la convivencia. Cuando don Quijote entra, lanza en ristre, a imponer su utopía de un mundo justo, que es lo que ha leído en las novelas de caballerías, lo único que consigue es crear más injusticias. Hay que ayudar a los demás. Grisóstomo no respeta la libertad de Marcela ni Anselmo la de su esposa Camila, a la que, además, le niega la ayuda que le pide. Para que no sobrevenga el caos hay que atenerse a ciertas normas morales. Cervantes las encuentra en el cristianismo, y además cuenta con la ayuda de Dios, con su gracia, sobre la que hay muchos textos.

Hatzfeld cita cinco textos de los que he citado en este apartado y uno sobre el cielo para concluir que Cervantes defiende "aquel espíritu ascéticomoral, apologético-racional y estrictamente eclesiástico del Catolicismo, tal como se instituye en los Ejercicios espirituales, de san Ignacio, por una parte, y en los cánones de Trento, por otra", y afirma "la entrega radical e incondi-

63 SPITZER, L., "Perspectivismo lingüístico en el Quijote”, en Lingüística e historia literaria, Gredos, Madrid 1955, p. 186.

${ }^{64} Q M, I, 14,168$. Léase la nota a este pasaje y la nota 4 de la página 1195 .

$65 L G$, VI, 615. Léase la nota a este pasaje.

66 Cf. $Q M, I, 15,174$.

$67 Q M$, I, 33, 430.

68 Cf. VEGA, J., "El diálogo", en Estudio Agustiniano, 35 (2002), pp. 330-340. 
cional [de Cervantes] a la Iglesia" y hasta presenta "una Iglesia hierárquica en miniatura" en el Quijote, en la que domina "el sentido verdadero que en la Iglesia militante debemos tener" (san Ignacio de Loyola)69. Afirmar esto con tal contundencia es como afirmar que todos estos textos provienen de Erasmo, o sea, no decir nada. Toda esta doctrina estaba en la tradición cristiana, y es ahí donde hay que situar a Cervantes, que estaba muy lejos de rendirse incondicionalmente a lo que dijera la jerarquía eclesiástica.

\subsection{El Paraíso terrenal y la Edad de Oro}

"Dios crió a nuestro primero padre en el Paraíso terrenal "70. La Edad de Oro era un lugar común en todas las literaturas. Con el humanismo, las descripciones de Catulo, Ovidio, Horacio y Virgilio estaban presentes siempre que se tocaba el tema. Los dos temas convivían y no interesa lo que a nosotros nos pueda parecer. La Edad de Oro no implica la defensa de una naturaleza inmanente, como no significa rechazar la creación, ni el pecado original, ni a Dios, ni a Jesucristo, ni el cristianismo. Los mismos autores espirituales hablan también de ella, como hablan de la vida rústica y pastoril, del elogio de la aldea y del menosprecio de la ciudad y la corte. "Rodéase en la cumbre / Saturno, padre de los siglos de oro"71.

"Cervantes se divierte con el concepto de los orígenes a lo largo de la obra" (el Quijote): ignora el lugar de origen del protagonista, el primer autor investiga en todas las fuentes a su alcance, el segundo autor encuentra fortuitamente un manuscrito arábigo, y la primera parte concluye con el hallazgo de una caja de plomo y un texto en pergamino carcomido. Las evasiones utópicas del protagonista y sus intentos de restaurar la Edad de Oro responden

${ }^{69}$ HATZFELD, H., El "Quijote" como obra de arte del lenguaje, CSIC, Madrid 1966, c. 3, pp. 133-134. Cf. ÍD., Estudios sobre el barroco, Gredos, Madrid 1966, c. 10, pp. 394-417, donde afirma también que Cervantes es contrarreformista e ignaciano, que criticaba a Erasmo y hacía de él un don Quijote tonto (p. 401). ¡Nada menos!. En un artículo de este mismo libro dice que Cervantes y Velázquez no eran tipos religiosos, sino militar uno y cortesano el otro, y que su interés estaba en la psicología humana (c. 9, pp. 364-393). Hatzfeld tiene el don particular de atar moscas por el rabo. Como muy bien vio Amado Alonso ("Don Quijote no asceta, pero ejemplar caballero y cristiano", en Materia y forma en poesía, edic. cit., pp. 148-186), mutila los textos y los tergiversa, y así va por donde quiere. Este artículo responde a otro de Hatzfeld, en el que afirmaba lo contrario de lo que dijo después: don Quijote no es contrarreformista, pertenece al Renacimiento italiano y a la "tendencia luterana de Erasmo y el erasmismo". ¿Cómo es posible pasar de un extremo a otro? No partía de los textos, sino que los adaptaba a sus ideas preconcebidas.

${ }^{70} Q M, \mathrm{I}, 33,424$.

71 LEÓN, fray Luis de, Poesía completa, edic. cit., 8 (noche serena), vv. 56-57. 
al deseo de regresar a unos orígenes prístinos. "Los orígenes y las fuentes no son sino eslabones de una cadena sin principio ni fin. Se resisten a la localización y la precisión, y su búsqueda es tan inútil como el intento de restaurar una edad de oro ilusoria"72.

Cuando un pastor en el Persiles habla de las comodidades que el uso ha introducido en el parto, está condenando las delicadezas añadidas por la costumbre y está proclamando el retorno a los orígenes, a la naturaleza, en vista de lo que ocurre en los animales; pero en el mismo texto se pone el ejemplo de Eva, la primera mujer, un ejemplo bíblico. "Sólo dificultó el ponerla en camino estando tan recién parida, y así se lo dijo, pero el anciano pastor dijo que no había más diferencia del parto de una mujer que del de una res, y que, así como la res, sin otro regalo alguno, después de su parto, se quedaba a las inclemencias del cielo, así la mujer podía, sin otro regalo alguno, acudir a sus ejercicios, sino que el uso había introducido entre las mujeres los regalos y todas aquellas prevenciones que suelen hacer las recién paridas.

-Yo aseguro -dijo más- que, cuando Eva parió el primer hijo, que no se echó en el lecho, ni se guardó del aire, ni usó de los melindres que ahora se usan en los partos"73.

Los tiempos presentes han añadido dolor al dolor y han multiplicado los vicios. Hay que retornar a las costumbres antiguas, al trato con la naturaleza, a la labranza y al pastoreo, a la vida sencilla, a la bondad primitiva. La tierra imprime y engendra en los que la labran "una bondad particular y una manera de condición sencilla, y un trato verdadero y fiel, y lleno de entereza y de buenas y antiguas costumbres" 74 . Y la vida pastoril es "vida sosegada y apartada de los ruidos de las ciudades y de los vicios y deleites de ellas. Es inocente, así por esto como por parte del trato y granjería en que se emplea [...]. $\mathrm{Y}$ es vivienda muy natural y muy antigua entre los hombres"75. "La fineza del sentir es del campo y de la soledad. $Y$ a la verdad, los poetas antiguos, y cuanto más antiguos tanto con mayor cuidado, atendieron mucho a huir de lo lascivo y artificioso, de que está lleno el amor que en las ciudades se cría, que tiene poco de verdad y mucho de arte y de torpeza"76. Si la verdad es inmutable, los antiguos tuvieron que conocerla y sólo quienes se aproximen a ellos, liberándose de los errores añadidos, podrán alcanzarla. "La antigüedad da peso a la doctrina, que la verdad, como no se muda, siempre es una, y siem-

\footnotetext{
72 PARR, J. A., “El Quijote y las aventuras diegéticas”, en Ínsula, 697-698 (2005), p. 22.

73 PS, III, 4, 462.

74 LEÓN, fray Luis de, La perfecta casada, edic. cit., c. 2, p. 95.

75 ÍD., De los nombres de Cristo, edic. cit., 1. I, Pastor, p. 221.

76 ÍD., ib., ib., p. 223.
} 
pre hubo quien la supiese. Pero las opiniones de error con los años se caen, y el tiempo las deshace y las borra, y así tienen siempre modernos principios. Por manera que la doctrina verdadera es duradera y antigua"77. Algo de esto resuena en la descripción del reino de una isla sin nombre, una utopía, un "no lugar": "Sus moradores le eligen [al rey] a su beneplácito, procurando siempre que sea el más virtuoso y mejor hombre que en él se hallara [...]. Con esto los pueblos viven quietos, campea la justicia y resplandece la misericordia, despáchanse con brevedad los memoriales de los pobres y, los que dan los ricos, no por serlo son mejor despachados; no agobian la vara de la justicia las dádivas ni la carne y sangre de los parentescos; todas las negociaciones guardan sus puntos y andan en sus quicios. Finalmente, reino es donde se vive sin temor de los insolentes y donde cada uno goza lo que es suyo"78.

Retornar a los orígenes, al paraíso perdido (los peregrinos del Persiles caminan hacia él), era también un postulado cristiano -los monjes lo sabían bien-, como lo era retornar a la Iglesia primitiva, a la comunidad de Jerusalén, Edad de Oro del cristianismo. Todo esto son tópicos que venían rebotando desde la antigüedad. La historia no tiene marcha atrás y la vuelta a los orígenes es imposible. Esa supuesta Edad de Oro, donde reinaban la justicia y la paz, y en la que los hombres rebosaban bondad y vivían en armonía con la naturaleza, no existió nunca. El elogio de la aldea con su inocencia y sus buenas costumbres, y de la vida pastoril, donde el amor es puro y transparente, no tiene nada que ver con la realidad. Idealizaciones e idealizaciones. Del Paraíso terrenal, el "jardín de las delicias" según los Padres de la Iglesia, todavía siguen hablando algunos, pero la ciencia nos impide seguir creyendo en él. El Paraíso es un mito, nunca fue realidad. No hubo un primer hombre y una primera mujer viviendo en un mundo feliz, creados en santidad y dotados de privilegios extraordinarios, sabios e inmortales. Si tan sabios eran, ¿cómo se dejaron engañar por la serpiente? La realidad fue exactamente al revés. El hombre emergió desde la animalidad. El terror y el canibalismo reinaban por doquier, la lucha por la vida. Aún hoy, después de tantos siglos de doma y labra, asoman por todas partes los peores instintos.

La descripción del Paraíso, a la entrada del gran parque temático que es la Biblia, expresa, según Th. Rey-Mermet, no lo que sucedió en los orígenes de la humanidad -felicidad y amistad divina-, sino lo que sucederá al final: es una profecía. Es la "maqueta" del gran proyecto de la creación. Adán y Eva anticipan lo que será la humanidad en su estado de perfección definitiva. "La

77 ÍD, Exposición del Libro de Job, estudio, edición y notas de Javier San José Lera, Ediciones Universidad de Salamanca, Salamanca 1992, vol. I, c. 15, $\mathrm{n}^{\circ} .18$, p.429.

78 PS, I, 22, 265. Léase la nota. 
humanidad no comenzó por seres perfectos, caídos a continuación en un estado inferior, sino por humildes bocetos que Dios va perfeccionando amorosamente según las leyes de un desarrollo lento"79. Y así, entre luces y tinieblas, avances y retrocesos, éxitos y fracasos, aciertos y descalabros se va haciendo la historia, hasta que toda la humanidad llegue a "la edad adulta, el desarrollo que corresponde al complemento del Mesías" (Ef 4,13), porque "la humanidad otea impaciente aguardando a que se revele lo que es ser hijos de Dios [...]. Esta humanidad abriga una esperanza: que se verá liberada de la esclavitud de la decadencia para alcanzar la libertad y la gloria de los hijos de Dios" (Rom 8,19-21). Y como la humanidad el individuo, que no nace hecho y derecho, colmado de perfecciones, sino que se va haciendo a lo largo de la vida, subiendo unas veces hacia las cumbres luminosas, retrocediendo otras, o despeñándose por los desgalgaderos, porque, como suele decirse, la ontogénesis repite la filogénesis, el individuo recorre los pasos de la especie.

De la Edad de Oro se podía echar mano, por ejemplo, para alabar a un personaje, como hizo ya Virgilio en la Égloga $I V$. Con su presencia los tiempos recobraban su antiguo esplendor, volvían los dias dorados. Con frecuencia el personaje carecía de relieve y hoy nos resulta desconocido. Con ella se podían recordar también momentos ya idos de la propia vida. "Cómo, a nuestro parecer, / cualquiera tiempo pasado / fue mejor", que escribió Jorge Manrique. "Edad dorada, siglo venturoso, / que gozar de tal hombre has merecido: / ¿cuál siglo, cuál edad ahora te llega, / si en ti está Marco Antonio de la Vega?"80. Fray Antonio recuerda su vida en el hampa: " $\mathrm{Oh}$ feliz siglo dorado, / tiempo alegre y venturoso, / adonde la libertad / brindaba a la voluntad / del gusto más exquisito!"81. Y la recuerda irónicamente Carriazo celebrando el amor de su amigo: "¡Oh amor platónico! ¡Oh fregona ilustre! ¡Oh felicísimos tiempos los nuestros, donde vemos que la belleza enamora sin malicia, la honestidad enciende sin que abrase, el donaire da gusto sin que incite!" 82 .

De la Edad de Oro en sentido estricto, del mito de la felicidad original, se habla en varios lugares. En aquel momento primigenio todo era luminoso. Nada estaba contaminado y el hombre vivía en la plenitud de la armonía con las cosas y con los demás hombres. Desde la situación concreta en que vive el personaje que la evoca, elige unas u otras características, pero siempre en su colmo, de modo que satisfagan los anhelos humanos.

79 Cit. por DelumeAU, J., Guetter l'aurore. Un christianisme pour demain, Bernard Grasset, Paris 2003, c. 5, p. 120.

${ }^{80} L G, \mathrm{VI}, 569$, estrofa 24 del Canto de Calíope.

$81 R D$, II, 344 .

82 IF, 400-401. 
Si habla un cautivo, para él la Edad de Oro es, ante todo, libertad. "¡Oh santa edad, por nuestro mal pasada, / a quien nuestros antiguos le pusieron / el dulce nombre de la edad dorada! / ¡Cuán seguros y libres discurrieron / la redondez del suelo los que en ella / la caduca, mortal vida vivieron! / No sonaba en los aires la querella / del mísero cautivo, cuando alzaba / la voz a maldecir su dura estrella. / Entonces libertad dulce reinaba / y el nombre odioso de la servidumbre / en ningunos oídos resonaba. / Pero después que sin razón, sin lumbre, / ciegos de la avaricia, los mortales, / cargados de terrena pesadumbre, / descubrieron los rubios minerales / del oro que en la tierra se escondía, / ocasión principal de nuestros males, / éste que menos oro poseía, / envidioso de áquel que, con más maña, / más riquezas en uno recogía, / sembró la cruda y la mortal cizaña / del robo, de la fraude y del engaño, / del cambio injusto y trato con maraña. / Mas con ninguno hizo mayor daño / que con la hambrienta, despiadada guerra, / que al natural destruye y al extraño. / Ésta consume, abrasa, echa por tierra, / los reinos, los imperios populosos, / y la paz hermosísima destierra, / y sus fieros ministros, codiciosos / más del rubio metal que de otra cosa, / turban nuestros contentos y reposos, / y, en la sangrienta guerra peligrosa, / pudiendo con el filo de la espada / acabar nuestra vida temerosa, / la guardan de prisiones rodeada, / por ver si prometemos por libralla / nuestra pobre riqueza mal lograda. / Y así, puede el que es pobre y que se halla / puesto entre esta canalla al daño cierto / su libertad a Dios encomendalla, / o contarse, viviendo, ya por muerto, / como el que en rota nave y mar airado / se halla solo, sin saber dó hay puerto. / Y no tengo por menos desdichado / al que tiene con qué y el modo ignora / cómo llegar al punto deseado, / porque esta gente, do bondad no mora, / no dio jamás palabra que cumpliese, / como falsa, sin ley, sin fe y traidora. / Guardará por su Dios al interese, / y do éste no interviene, no se espere / que por sola virtud bondad hiciese"83.

Los hombres descubrieron el oro oculto en la tierra. La avaricia y la envidia de los que menos tenían desataron sobre la tierra el fraude, los cambios injustos y las guerras, y con las guerras los vencidos quedaron sometidos como cautivos, y los vencedores sólo por dinero les devuelven la vida y la libertad. Casalduero ve en este largo parlamento una contraposición entre la Edad de Oro y la actualidad española, oro y guerras, y los sentimientos del propio Cervantes al ver comprometida la modesta posición económica de su familia por su cautiverio y el de su hermano ${ }^{84}$.

83 TA, II, 128-129.

84 Cf. CASAlduERo, J, Sentido y forma del teatro de Cervantes, Gredos, Madrid 1966, pp. 238-239. 
El zagal Clemente, pobre, pero bueno, pide justicia para que su esposa, que tiene cubierta la cara con un velo y es hija del alcalde repita el sí públicamente, que antes le dio en matrimonio clandestino, "a hurto de su padre" rico. Si el alcalde está dispuesto a hacerla, veremos de nuevo los años dorados. "Los siglos que renombre de dorados / les dio la antigüedad con justo intento, / ya se ven en los nuestros, pues que vemos / en ellos de justicia los extremos" 85 .

Don Quijote y Sancho se encuentran con unos cabreros y éstos les ofrecen una buena comida. Después de haber comido la carne, tienden sobre pieles de oveja una gran cantidad de bellotas dulces. Don Quijote toma un puñado en la mano, las bellotas aparecen con frecuencia en las descripciones renacentistas de la Edad de Oro, y se despacha a su gusto en una arenga por todo lo alto ${ }^{86}$. Se aureola el pasado, pero a la vez se introducen temas actuales. Entonces había comunidad de bienes, tema de raigambre estoica. La tierra daba todo lo necesario. Todo era paz, armonía y concordia. Las zagalas, "en trenza y en cabello", con la cabeza descubierta como doncellas y jóvenes que eran, andaban libremente por los campos, reducido el vestido a lo imprescindible ${ }^{87}$. Ahora, en cambio, las cortesanas ociosas van vestidas de púrpura y seda. Antes, la belleza natural, sin afeites; ahora, el lujo se ha desbordado. Entonces el amor se expresaba con sencillez, sin rodeos; ahora, todo es artificioso. Tema de la sencillez y llaneza del estilo, tan frecuente en Cervantes ${ }^{88}$. La justicia estaba entonces en su punto; ahora, la ley del encaje: tema social muy presente en él. Retorna el tema de la honestidad de las doncellas. "Su perdición nacía de su gusto y propia voluntad; ahora "no está segura ninguna", aunque se encierren tras rejas y candados, porque hasta allí llega "la amorosa pestilencia". Cervantes está en contra de la guarda de las mujeres. Son ellas las que tienen que guardarse y ejercer su libertad. La pastora Marcela asoma ya en el horizonte. Para corregir el ahora se estableció la Orden de Caballería, a la que pertenece don Quijote, que está dispuesto a restaurar el entonces.

$85 P U, \mathrm{I}, 504$.

86 Cf. $Q M, I, 11,133-135$. Léanse las notas a este pasaje. Las referencias al Nuevo Testamento, a los Evangelios y a I Corintios son frecuentes. Expresan la voluntad de relacionar esta "rústica cena" al modelo de la última Cena de Jesucristo. Cf. BLASCO, J., Don Quijote de la Mancha, edic. cit., volumen complementario, lecturas del "Quijote", I, 11, pp. 4143.

${ }^{87} Q M, \mathrm{I}, 9,117$ : "Andaban [...] con toda su virginidad a cuestas, de monte en monte y de valle en valle". Anticipa el episodio de Marcela.

${ }^{88} Q M$, I, prólogo, 19: "dando a entender vuestros conceptos sin intricarlos y escurecerlos". $Q M$, II, 26, 927: "Llaneza, muchacho, no te encumbres, que toda afectación es mala". 
Pero aquí está también la realidad de los cabreros, inhóspita, arisca, pronta a hacer añicos el mundo idealizado y terso de la Arcadia y la luz sin mácula de los siglos dorados. La vida se encarga de echar por tierra toda construcción utópica, como echa abajo una y otra vez el mesianismo de don Quijote, siempre por él afirmado y siempre destruido por la dura realidad. Cervantes pincha el mito y lo desinfla. Es la técnica cervantina de encarar los temas desde distintos ángulos. Los cabreros han estado suspensos, como quien ve visiones. Este es el escenario: unos cabreros, un dornajo, pieles de ovejas, tasajo de cabra, dos odres, medio queso duro y muchas bellotas. "Toda esta larga arenga (que se pudiera muy bien excusar) [...]. Y antojósele hacer aquel inútil razonamiento a los cabreros, que, sin respondelle palabra, embobados y suspensos, le estuvieron escuchando"89. Pero el capítulo está perfectamente estructurado entre discurso y realidad, entre literatura y vida, y prepara los capítulos siguientes.

Cervantes utiliza la Edad de Oro en diversos contextos y en cada ocasión actualiza alguna de las muchas virtualidades en ella latentes. "Yo nací por querer del cielo en esta nuestra edad de hierro para resucitar en ella la de oro, o la dorada, como suele llamarse"90. Don Quijote proyecta sus utopías caballerescas, acordes con la Edad de Oro, sobre el tiempo presente y pretende instaurarla de nuevo en la tierra. Esto no podría hacerlo si hablase del Paraíso. "Pero no es merecedora la depravada edad nuestra de gozar tanto bien como el que gozaron las edades donde los andantes caballeros tomaron a su cargo la defensa de los reinos [...]. Mas agora ya triunfa la pereza de la diligencia, la ociosidad del trabajo, el vicio de la virtud, la arrogancia de la valentía y la teórica de la práctica de las armas, que sólo vivieron y resplandecieron en las edades del oro y en los andantes caballeros"91. La condenación de los tiempos presentes y la inversión de los valores morales es uno de los temas que con más frecuencia se repiten ${ }^{92}$. Los predicadores de todos los tiempos lo han utilizado como uno de los recursos más fáciles y que más complacen al auditorio, al oír por enésima vez la maldad de los que no están en el sermón.

Don Quijote alude a su mesianismo recordando un texto en que Jesucristo pregunta a sus discipulos quién dice la gente que es él. "Dime, Sancho amigo, qué es lo que dicen de mí por ese lugar. ¿En qué opinión me tiene el vulgo, en qué los hidalgos y en qué los caballeros? ¿Qué dicen de mi valentía,

${ }^{89} Q M, \mathrm{I}, 11,135$.

${ }^{90} Q M, \mathrm{I}, 20,227$.

${ }^{91} Q M$, II, $1,690-691$.

92 Cf. MÁRQUez VillanueVA, F., "La actitud espiritual del Lazarillo de Tormes", en Espiritualidad y literatura en el siglo XVI, Alfaguara, Madrid-Barcelona, 1968, pp. 82-87. 
qué de mis hazañas y qué de mi cortesía? ¿Qué se platica del asunto que he tomado de resucitar y volver al mundo la ya olvidada orden caballeresca? Finalmente, quiero, Sancho, me digas lo que acerca desto ha llegado a tus oídos, y esto me has de decir sin añadir al bien ni quitar al mal cosa alguna [...]. Si a los oídos de los príncipes llegase la verdad desnuda, sin los vestidos de la lisonja, otras edades serían tenidas por más de hierro que la nuestra, que entiendo que de las que ahora se usan es la dorada"93.

\subsection{El pecado original}

Cervantes, de acuerdo con el cristianismo, atribuye los males que hay en la tierra al pecado original y a los pecados que cometen los hombres. También aquí disiento de la interpretación de Américo Castro: "El autor admitirá, por espíritu de Contrarreforma, la doctrina del pecado original, lo que está en contradicción con la hipótesis de la perfección natural de todos los humanos que, como veremos, exigen el tema de la Edad de Oro y sus afines. Y cuando Cervantes sonría melancólico ante la imposibilidad de la perfección natural, no irá guiado por motivos teológicos"94. Castro parte de "la naturaleza como principio divino e inmanente" en Cervantes, pero ya hemos visto que la naturaleza ha sido creada por Dios, "mayordoma de Dios". De inmanencia nada de nada. Los textos ya citados prueban claramente su cristianismo. Los que siguen lo corroborarán con otros muchos que se pudieran citar.

"Vuelvo a decir lo que otra vez he dicho: que el hacer y decir mal lo heredamos de nuestros primeros padres y lo mamamos en la leche. Vese claro en que apenas ha sacado el niño el brazo de las fajas, cuando levanta la mano con muestras de querer vengarse de quien, a su parecer, le ofende; y casi la primera palabra articulada que habla es llamar puta a su ama o a su madre" 95 . "No me maravillo, Berganza; que como el hacer mal viene de natural cosecha, fácilmente se aprende el hacerle" 96 . Pero, a la vez, Cervantes elogia la bondad y la caridad, que vienen también "de natural cosecha". En esta misma obra se nos dice: "No sé qué tiene la virtud, que, con alcanzárseme a mí tan poco o nada de ella, luego recibí gusto de ver el amor con que aquellos benditos padres enseñaban a aquellos niños" 97 . Prescindo de la ironía que rezuma el texto

${ }^{93} Q M$, II, 2, 700. El sentido de la última frase es ininteligible. Cf. Mc 8, 27-30; Mt 16, 13-20; Lc 9, 18-21.

${ }^{94}$ CAStro, A., El pensamiento de Cervantes, edic. cit., c. 4, p. 167.

${ }^{95} \mathrm{CP}, 562$.

${ }^{96} C P, 546$.

${ }^{97} \mathrm{CP}, 563$. 
sobre "aquellos benditos padres". "El ánimo, que de suyo no es bueno"98. Pero unas páginas más adelante dice el mismo autor: "La naturaleza nuestra, buena ella de suyo e inclinada a lo que es mejor" 99 .

Depende del ángulo de visión que se adopte. La naturaleza fue creada buena por Dios, pero la ponzoña del pecado original la dañó y envenenó, aunque no sustancialmente como sostenían Lutero y Calvino. "La naturaleza, madre diligente y proveedora de todo lo que toca al bien de lo que produce", guía los animales, las plantas y "hasta las cosas más viles" eficazmente a sus fines. ¿Cómo ha podido crear "a la más principal de todas tan inclinada al pecado"? En ella hay "alguna enfermedad y daño encubierto" y no está tan "pura como salió de las manos del que la hizo, sino dañada y corrompida" 100.

Don Quijote entra en Barcelona la mañana de san Juan rodeado de caballeros, una mañana espléndida, el mar alegre, el aire puro, al son de chirimías y atabales. Pero "el malo [el diablo] que todo lo malo ordena, y los muchachos que son más malos que el malo, dos dellos traviesos y atrevidos se entraron por toda la gente y, alzando el uno de la cola del rucio y el otro la de Rocinante, les pusieron y encajaron sendos manojos de aliagas"101. No son mejores los que siguen al Licenciado Vidriera: "Los muchachos, que son la más traviesa generación del mundo, a despecho de sus ruegos y voces, le comenzaron a tirar trapos, y aun piedras por ver si era de vidrio. [...] ¿Qué me queréis, muchachos, porfiados como moscas, sucios como chinches, atrevidos como pulgas? ¿Soy yo, por ventura, el monte Testacho de Roma, para que me tiréis tantos tiestos y tejas?"102.

Viene bien aquí un texto de fray Luis de Granada: "Vemos en la edad tierna de los muchachos, antes que puedan pecar, las semillas de estos males, (porque entonces comienza a descubrirse la envidia, la insidia, el odio, la rabia, el deseo de venganza y otras semejantes pasiones, las cuales no vienen por pecados propios porque aún no los tienen.); por lo cual habemos de confesar que pues todos los hombres nacen con estas malas inclinaciones, y no por pecados propios actuales, que algún pecado hubo en algún hombre que fue principio de toda la generación humana, el cual por su culpa quedó sen-

98 LEÓn, fray Luis de, De los nombres de Cristo, edic. cit., 1. 1, Monte, p. 255.

99 ÍD., ib., 1. 1, Padre del siglo futuro, p. 275.

100 ÍD., ib., 1. II, Dedicatoria, pp. 311-312. Fray Luis habla de la naturaleza, "madre diligente y proveedora de todo lo que toca al bien de lo que produce", que encamina todas las cosas hacia sus fines. ¿Se podría hablar de la "naturaleza divina e inmanente"? Evidentemente no. En las cosas que hace está Dios. De Cervantes hay que decir lo mismo.

$101 Q M, \mathrm{II}, 61,1236$.

102 LV ,278-279. El monte Testacho se había formado por la acumulación de cacharros -tiestos-, tejas y ladrillos. 
tenciado a esta pena, y cual él quedó, tales nos engendró a todos"103. Muchos siglos antes lo había dicho san Agustín: "¿Quién me recordará el pecado de mi infancia, ya que nadie está limpio de pecado en tu presencia, ni aun el niño de un día? ¿Quién me lo recordará? ¿Acaso algún chiquirritín en quien veo lo que no recuerdo en mí? ¿Y en qué pecaba yo entonces? ¿Acaso en desear con ansias y lloros el pecho? [...] Luego ya entonces hacía cosas dignas de reprensión [...]. ¿Tal vez era entonces bueno pedir llorando lo que, de dármelo, hubiera sido nocivo? ¿Indignarse agriamente con las personas libres que no se me sometían y aun con los propios padres? ¿Esforzarse con toda el alma por golpear a otros muchos que, más prudentes, no accedían a mis caprichos ni obedecían mis mandatos, que hubiera sido perjudicial obedecer? Así pues, la debilidad de los miembros infantiles es inocente, no su ánimo. Vi y experimenté yo a un niño envidioso. Aún no hablaba y ya miraba, pálido, a su hermano de leche con torva mirada"104. La consecuencia es clara. Si la naturaleza humana está tan corrompida en sus mismos orígenes, antes que haya podido ser maleada por los usos, es que lleva dentro el veneno de algún pecado gravísimo cometido por el primer hombre y heredado por todos a través del sexo. Y así se ha seguido repitiendo siglos y siglos.

Se recuerda la maldición bíblica. "En verdad que comemos el pan en el sudor de nuestros rostros, que es una de las maldiciones que echó Dios a nuestros primeros padres"105. De los comediantes se dice: "En el sudor de su cara ganan su pan, con inllevable trabajo" 106 . Y se describe el pecado original con las consecuencias sabidas de todos. "Luego que el atrevido primer padre nuestro pasó el divino mandamiento, y de señor quedó hecho siervo, y de libre, esclavo, luego conoció la miseria en que había caído y la pobreza en que estaba; y así tomó en el momento las hojas de los árboles que le cubriesen, y sudó y trabajó rompiendo la tierra para sustentarse y vivir con la menos incomodidad que pudiese; y tras esto, obedeciendo mejor a su Dios en ello que en otra cosa, procuró tener hijos y perpetuar y dilatar en ellos la generación humana. Y así como por su inobediencia entró la muerte en él y por él en todos sus descendientes, así heredamos juntamente todos sus afectos y pasiones, como heredamos su misma naturaleza"107. El hombre quedó aherrojado con "la cadena del hierro antiguo", condenado a "muerte" espiritual y biológica, en "mortal discordia" con Dios, vestido de "luto" por "la gran culpa pri-

103 Fray LUIS DE GRANADA, Símbolo de la fe. Cit. por A. Castro, El pensamiento de Cervantes, edic. cit., c. 4, p. 177 , n. 85.

104 San AGUSTín, Confesiones I, 7, 11 .

$105 Q M$, II, 13, 792. Cf. Gn 3, 19 .

$106 L V, 292$.

$107 L G$, IV, 437. 
mera"; pero a la vez se habla "de la culpa dichosa de Adán"108, expresión que explicaré al hablar de la Redención.

Adán era señor de sus pasiones y de toda la creación, era libre. Al desobedecer a Dios rompiendo la jerarquía, era justo que todo se rebelara contra él, y, en primer lugar, sus deseos; pero también toda la naturaleza y las criaturas que hay en ella. De señor se convirtió en esclavo, encadenado al pecado. Su dignidad quedó convertida en miseria. Los autores hablarán de la dignidad del hombre creado por Dios y de la dignidad del cristiano por la gracia, pero a la vez de su miseria por el pecado. La naturaleza creada por Dios sigue siendo buena y digna, pero la naturaleza actual está contaminada, es despreciable. Dignidad y miseria del hombre. Sólo a partir de la Ilustración se hablará de la dignidad humana por el mero hecho de ser hombre. Al heredar la naturaleza de Adán, heredamos con ella sus inclinaciones al mal, la concupiscencia, la esclavitud y la muerte. "Este desconcierto e inclinación para el mal que los hombres generalmente tenemos, él solo por sí, bien considerado, nos puede traer en conocimiento de la corrupción antigua de nuestra naturaleza. En la cual naturaleza, habiendo sido hecho el hombre por Dios enteramente señor de sí mismo, y del todo cabal y perfecto, en pena de que él por su grado [voluntad] sacó su ánima de la obediencia de Dios, los apetitos del cuerpo y sus sentidos se salieron del servicio de la razón, y, rebelando contra ella, la sujetaron, oscureciendo su luz y enflaqueciendo su libertad, y encendiéndola en el deseo de sus bienes de ellos, y engendrando en ella apetito de lo que le es ajeno y la daña, esto es, del desconcierto y pecado" 109 .

Por el pecado de Adán entró la muerte en el mundo y en todos sus descendientes ${ }^{110}$. Pero la muerte es un hecho biológico, un proceso natural, programado en las células, no un castigo. La teoría que se impuso sobre el pecado original fue la de san Agustín, pero antes había habido otras no tan trágicas, como la de san Teófilo de Antioquía y la de san Ireneo a finales del siglo II. El pecado original no aparece en los evangelios, ni figura en el Símbolo de

108 PS, III, 5, 480-482.

109 LEÓN, fray Luis de, De los nombres de Cristo, edic. cit., 1. 2, dedicatoria, p 313. La oposición siervo / señor y otras similares para indicar las relaciones entre las facultades inferiores y la razón, que otras veces servían para señalar las relaciones entre las ciencias y la filosofía o entre ésta y la teología según la fórmula medieval philosophia ancilla theologiae, se encuentra ya en Cicerón. Aparece en varias obras de Filón de Alejandría y en los $\mathrm{Co}$ mentarios a los salmos 145, 5, de san Agustín, pasando después a las literaturas románicas, en las que es muy conocida. Cf. LIDA DE MALKIEL, M. R., "Una copla de Jorge Manrique y la tradición de Filón en la literatura española", en Estudios sobre la literatura española del siglos $X V$, José Porrúa Turanzas, Madrid s. a., pp. 145-178.

110 Cf. Gn 2, 17; 3, 19; Rm 5, 12-21; 1 Cor 15, 21-22. 
los Apóstoles, ni en el de Nicea. Es también extraño a la tradición judía, a pesar del salmo 51, 7 .

Pero el mal existe y existe en las tres dimensiones del hombre, individual, social e histórica ${ }^{111}$. Existe también la dimensión cósmica. Como bien vio Lamarck, hay una conexión inextricable entre los organismos y su biosfera. $\mathrm{El}$ universo es un infinito tejido de interrelaciones, en el que todo está conectado con todo. Hay en el cerebro del hombre zonas oscuras de rencor y odio, de venganza y violencia, pero hay también en él zonas luminosas de generosidad y tolerancia; inclinación al mal y al bien. El hombre es un ser en devenir, se está haciendo siempre dentro de sus limitaciones. Existe la maldad, la voluntad de poder, que no respeta a nadie; el ansia de riqueza, la concupiscencia, que todo lo arrasa. Esos pecados terminan enquistándose en la sociedad, creando leyes y estructuras injustas, nuevas esclavitudes, y todo ello se transmite históricamente. "El pecado original no hay que buscarlo en cualquier forma de transmisión biológica entre dos individuos que, de lo contrario, vivirían completamente aislados, sino en esa red colectiva que precede a la existencia individual como antecedente espiritual. Hablar de transmisión es afirmar que el hombre no puede empezar su existencia en un punto cero, en un status integritatis, sin relación alguna con la historia. Nadie se halla en un estadio inicial sin relación alguna en el que uno pueda realizarse a sí mismo y desplegar sus propias virtualidades"112. Por dicha, existe también la bondad, estructuras justas y leyes humanas en favor de las personas, y esto afecta también a las cuatro dimensiones humanas. Vivimos inmersos en un mundo en el que se entrelazan el amor y el odio, la gracia y el pecado, la redención y la esclavitud. Y somos permeables a todo ello en el proceso de socialización. Jean Delumeau ha propuesto cambiar la expresión "pecado original", "doctrina de la que hay que desembarazarse totalmente" porque identificó a Adán, nombre colectivo, con el primer hombre, por la frase que utiliza el evangelista Juan, "pecado del mundo", que Jesús vino a "quitar" $(\mathrm{Jn} 1,29)^{113}$.

Ante el mal se pueden adoptar muchos puntos de vista. Es la hora de analizar detenidamente las causas reales, siempre muy complejas, para buscar sus remedios y seguir escalando hacia la cumbre del bien. La mirada de Cervantes es comprensiva. No hay hombre tan malo que no tenga en él un rayo de bondad. En el desvalimiento del hombre, él, amante de la vida, sabe ver el

111 Cf. ZUBIRI, X., Tres dimensiones del ser humano: individual, social, histórica, Alianza, Madrid 2006.

112 RATZINGER, J., Introducción al cristianismo, Sígueme, Salamanca 19794, c. 8, p. 214.

113 DelumeAU, J., Guetter l'aurore. Un christianisme pour demain, edic. cit., c. 5, pp. 97-126. La cita está en las pp. 118-119. 
lado favorable, la brasa no extinta de la bondad, lo que se resuelve en una aceptación amorosa de la condición humana.

\subsection{Dios, centro del hombre}

En la cima de la escala de los seres está Dios, al que orientan sus deseos las criaturas todas como a su centro. La amada es también el centro de los deseos del amante. Me interesan únicamente los textos que se refieren a Dios. "Llamo centro un punto indivisible a quien todas las líneas de su circunferencia van a parar"114. "Ha de estar siempre nuestra alma en continuo movimiento"115. "Viendo el hacedor y criador nuestro que es propia naturaleza del ánima nuestra estar contino en perpetuo movimiento y deseo, por no poder ella parar sino en Dios, como en su propio centro"116. le puso de centinela la razón para que refrene sus deseos. "El amor honesto mira a las cosas del Cielo, eternas y divinas [...]. El amor honesto sólo en Dios para y sosiega"117. "Nuestras almas están siempre en continuo movimiento, sin que puedan dejar de estar atentas a querer bien a algún sujeto"118. "Como están nuestras almas siempre en continuo movimiento, y no pueden parar ni sosegar sino en su centro, que es Dios, para quien fueron criadas, no es maravilla que nuestros pensamientos se muden, que éste se tome, aquél se deje, uno se prosiga y otro se olvide, y el que más cerca anduviere de su sosiego, ese será el mejor, cuando no se mezcle con error de entendimiento"119. "Nuestras almas, como tú bien sabes y como aquí me han enseñado, siempre están en continuo movimiento y no pueden parar sino en Dios, como en su centro" 120 .

Se ha dicho que en estos textos Cervantes está recordando la famosa frase de san Agustín en las Confesiones: "Nos has hecho para Ti y nuestro corazón está inquieto hasta que descanse en Tí"121. Casi al final dice esta otra: "También nosotros después de nuestras obras, muy buenas porque Tú nos las

$114 P S$, III, $11,542-543$.

115 PU, III, 532.

$116 L G, I V, 440$.

${ }^{117} L G, I V, 436-437$.

118 PS, II, 3, 293. El editor, en la n. 4, dice que Auristela recuerda, adaptándolas a un amor "mundano", "las conocidísimas palabras de san Agustín sobre la inquietud fundamental del alma, mientras no repose en su centro, Dios"(Confesiones 1,1). Cf. n. $238 \mathrm{del}$ anterior artículo.

$119 P S$, III, 1, 429. El editor afirma en nota a este pasaje que "este concepto -y hasta la forma- de la frase es directamente agustiniano".

120 PS, IV, 10, 690.

121 SAN AGUSTÍn, Confesiones 1, 1,1. 
has dado, descansaremos en Ti el sábado de la vida eterna"122. Aquí no se habla para nada del movimiento continuo de las almas. "Nuestro descanso es nuestro lugar. El amor nos levanta hacia allí [...]. El cuerpo por su peso tiende a su lugar. El peso no sólo impulsa hacia abajo, sino a su lugar. El fuego tiende hacia arriba, la piedra hacia abajo: los dos son movidos por su peso, tienden a su lugar. El aceite derramado bajo el agua se coloca sobre ella; el agua derramada sobre el aceite se sumerge bajo ella: los dos son movidos por su peso, buscan su lugar. Las cosas fuera de su orden están inquietas; se las ordena y descansan. Mi peso es mi amor; dondequiera soy llevado, es él quien me lleva"123. Los textos de san Agustín se sitúan claramente en el contexto cultural de su época, herencia de los griegos: lugar natural, peso-amor, centro, inquietud, reposo... Pero los ha transformado totalmente. Ha convertido la mecánica sublunar en antropología, en experiencia personalísima suya e intransferible. Los ha hecho vida de su vida y les ha dado un significado preciso con una intensidad y una orientación hacia Dios única, exclusivamente suya. Este peso-amor no tiene ya nada que ver con el peso-amor inercial de los cuerpos celestes. "La intuición de san Agustín no está muy lejos de la idea de vector: el amor es el peso que nos lleva a uno u otro lugar, en una u otra dirección" 124 .

Naveguemos aguas arriba hasta Platón y Aristóteles. Que las almas están en continuo movimiento y que son fuente y principio de todo lo demás que se mueve está en Platón ${ }^{125}$. Dios, según Aristóteles, no ama, no puede amar, porque sería depender de lo corruptible. En cambio, sí puede ser amado. Dios, motor inmóvil, atrae hacia sí al primum mobile "en cuanto amado"126 y éste arrastra consigo las demás esferas celestes (Luna, Mercurio, Venus, Sol, Marte, Júpiter, Saturno, el cielo de las estrellas fijas, el cielo cristalino o de las aguas. Estas esferas tenían vida e incluso inteligencia.). "Veré los movimientos celestiales, / ansí el arrebatado, / como los naturales"127. Dante, en el último verso de la Divina comedia, dice: "el amor mueve el Sol y las otras estrellas", es decir, todas las esferas son atraídas por el primum mobile, que es atraído

122 ÍD., Confesiones 13, 36, 51 .

123 ÍD., Confesiones 13, 9, 10.

124 MARÍAS, J., Antropología metafísica, edic. cit., c. 23, p. 204.

125 PlATÓn, Fedro o de la belleza $245 \mathrm{c}$.

126 ARISTÓTELES, Metafísica 1072 b: "La causa final mueve en cuanto que es amada, mientras que todas las demás cosas se mueven al ser movidas". Cf. VEGA, José, La vocación agustiniana. El proyecto filosófico-monástico-sacerdotal de san Agustín, Estudio Agustiniano, Valladolid 1987, c. 27, pp. 533-539.

127 LEÓn, fray Luis de, Poesías completas, edic. cit., X, vv. 52-54. El editor explica este pasaje: el movimiento arrebatado es el de cada esfera arrastrada por el décimo cielo, el primum mobile; el natural es el propio de cada esfera. 
por Dios en cuanto que le ama. Hay un orden y dentro de ese orden cada cosa tiene su lugar "natural", su centro, y tiende hacia él: " "El orden es la distribución de los seres iguales y diversos, asignándole a cada uno su lugar"128. Esa tendencia se llama peso, afinidad, inclinación, instinto, simpatía, amor... ${ }^{129}$ Todas las cosas, incluidos los hombres, aman naturalmente a Dios (éstos le pueden amar también sobrenaturalmente). Los escolásticos heredaron esta doctrina sin distinción de escuelas. Las almas estan en continuo movimiento. Todo está en movimiento menos Dios. De aquí la vía del movimiento para demostrar su existencia. Todo lo imperfecto se mueve hacia lo perfecto. Dios, que es la perfección absoluta, no puede moverse. Es el centro de todas las criaturas y en él descansan y se aquietan.

Si cotejamos los textos de Cervantes con los de san Agustín y los de la escolástica, me parece evidente que sigue a ésta y no a áquel. No es que Cervantes fuera fílósofo y teólogo, pero todas estas ideas corrían por los libros espirituales y profanos y se oían en los sermones. "El corazón y la inquietud agustinianas, experiencias personales, han sido sustituidos por el alma y el movimiento, términos de la metafísica escolástica" 130 .

\section{10. El hombre al servicio de Dios}

La vida del hombre se concebía como servicio, no como entrega a los demás, que es la visión cristiana ${ }^{131}$, sino como sumisión de los de abajo a los de arriba, "a los mayores en edad, dignidad y gobierno", que decía el catecismo de Astete. La cadena del ser existía también en las clases sociales. Entrar

128 SAN Agustín, La Ciudad de Dios 19, 13,1.

129 Sobre las distintas clases de movimientos, sobre el peso y el lugar natural, sobre la mecánica sublunar en la antigüedad, cf. SAMBURSKY, S., El mundo físico a finales de la antigüedad, Alianza, Madrid 1990, pp. 76-110.

130 Morón ARroyo, C., Nuevas meditaciones del "Quijote ", Gredos, Madrid 1976, c. 3, p. 113 .

131 Tiene razón ORTEGA Y GASSET, J.: un ministro socialista, "tan denodada y ruidosamente ateo", pronunció un discurso en Oviedo, donde afirmó que "la legión socialista, ésta nuestra, cada día en mayor cohesión por ese nuevo espíritu religioso, casi ya tan fuerte como el cristianismo, que se llama solidaridad obrera [...]. Me tracé el designio de servir de por vida a todos los desvalidos [...]". Comenta Ortega: "Quiera o no el ministro socialista, eso es esencial al cristianismo -es cristianismo en hueco-. Si no hubiera habido cristianismo, no se le habría ocurrido a este hombre dedicar su vida a algo. He ahí lo fundamental de la experiencia cristiana del hombre: todo lo demás es secundario, casi anecdótico al lado de esto. [No ocuparse en esto o aquello], sino descubrir, caer en la cuenta de que la vida en su última sustancia consiste en tener que ser dedicada a algo [...]. Ésa es la averiguación fundamental del cristianismo, lo que indeleblemente ha puesto en la historia, es decir, en el hombre [...]. Pero desde el cristianismo el hombre, por ateo que sea, sabe, ve, no ya que la 
a servir en una clase superior era pasar de un eslabón a otro más elevado; participar, de alguna manera, de su honra y gloria. Servir a los nobles, servir a los grandes, servir al rey, servir a la amada, servir a Dios, servir a Dios y al rey... Servir era una de las palabras más usadas en todos los textos. Para servir a Dios y a las buenas gentes, para servir a Dios y a vuesa merced... se repetía en el lenguaje coloquial. Se sirve a Dios o se sirve al mundo en el lenguaje de los ascetas. Servir a alguien era dejarse gobernar por él, obedecerle y honrarle. Las inclinaciones de cabeza y el humildoso doblar el espinazo de los súbditos eran muy estimados. "Quien comienza a amar debe también comenzar a obedecer y a conformarse totalmente con la voluntad de la persona a quien ama, y con ella gobernar la suya, y hacer que sus deseos sean como esclavos, y que su misma alma sea como sierva, y que no piense jamás sino en transformarse, si posible fuese, en la cosa amada, y esto ha de tener por su mayor y más perfecta bienaventuranza; porque así lo hacen los que verdaderamente aman"132. En este contexto escribe san Ignacio: "El hombre es criado para alabar, hacer reverencia y servir a Dios nuestro Señor"133. El hombre ha sido creado "para servir a Dios en esta vida y después gozarle en la eterna", repetían los catecismos.

El hombre se veía a sí mismo a través de los ojos de los demás, especialmente de aquél a quien servía. La imagen que tenía de sí mismo era inseparable de la que le ofrecían los demás. Lo que los demás pensaban de él lo interiorizaba y esa era su identidad. La honra no era algo propio de la persona, era lo que los demás pensaban de ella. "Ningún hombre es honrado por sí mismo, / que del otro recibe la honra un hombre. / Ser virtuoso un hombre y tener méritos, / no es ser honrado... De donde es cierto, / que la honra está en otro y no en él mismo", dice Lope de Vega en Los comendadores de Córdo$b a^{134}$. Era el grupo el que prevalecía sobre el individuo.

Pero por diversos caminos iba surgiendo el individuo. Cada uno es hijo de sus obras, repite Cervantes. "Dulcinea es hija de sus obras, y que las virtu-

vida humana debe ser entrega de sí misma, vida como misión premeditada y destino interior -todo lo contrario que aguante de un externo destino [estoicismo]-, sino que lo es, queramos o no. Díganme ustedes qué otra cosa significa la frase tan repetida en el Nuevo Testamento y como casi todo el Nuevo Testamento tan paradójica: El que pierde su vida es el que la gana. Es decir, da tu vida, enajénala, entrégala; entonces es verdaderamente tuya, la has asegurado, ganado, salvado" (En torno a Galileo. Esquema de las crisis, Espasa-Calpe, Madrid 1965, lección XII, pp. 222-224).

132 CASTIGLIONE, B. de, El cortesano, edic. cit., 1. 3, c. 6, p. 283.

133 SAN IGNACIO DE LOYOLA, "Ejercicios", en Obras completas, edic. cit., principio y fundamento, $\mathrm{n}^{\circ} 23, \mathrm{p} .161$.

134 Cit. por CASTRO, A., "Honra y limpieza de sangre", en De la edad conflictiva, Taurus, Madrid 1961, p. 73. 
des adoban la sangre, y que en más se ha de estimar y tener un humilde virtuoso que un vicioso levantado"135. La nobleza, y no hay que entenderlo metafóricamente, se transmitía por la sangre, en términos fisiológicos, pero "la verdadera nobleza consiste en la virtud"136. "Cada cual se fabrica su destino; / no tiene allí fortuna alguna parte"137. Cada uno es hijo de sus acciones, no de su linaje. La ciencia había demostrado que no hay diferencias de sangre entre los individuos de los distintos estamentos. "Sábete, Sancho, que no es un hombre más que otro, si no hace más que otro"138

"Con gran dificultad, el día de hoy, halla un hombre de bien señor a quien servir. Muy diferentes son los señores de la tierra del Señor del cielo; aquéllos, para recibir un criado, primero le espulgan el linaje [...]; pero para entrar a servir a Dios, el más pobre es más rico; el más humilde, de mejor linaje; y con sólo que se disponga con limpieza de corazón a querer servirle, luego le manda poner en el libro de sus gajes [el Libro del registro de los vivos (Ap, 20, 12)], señalándoselos tan aventajados, que, de muchos y de grandes, apenas pueden caber en su deseo"139. "Espulgar el linaje" o "deslindarlo"140, como se decía también, era averiguar cuiadosamente sobre su familia, sobre su honra y estamento social. Se alude a los problemas en relación con la hidalguía y la compra de títulos ${ }^{141}$. En ese "espulgar el linaje" entraba también la limpieza de sangre ${ }^{142}$. Limpieza de corazón frente a limpieza de sangre, que dividía a los cristianos en viejos (puros de sangre, limpios) y nuevos o conversos ( manchados con sangre judía o mora). En consonancia con los textos sobre los atributos divinos, se trata de un servicio muy peculiar. No hay aquí normas señoriales, honores y boato. Cuanto más pobre y humilde, mejor. Dios es el Padre de una gran familia, del que están muy lejos los señores de la tierra con sus invenciones y comportamientos.

$135 Q M$, II, 32, 980.

$136 Q M, I, 36,469$. La verdadera nobleza es la virtud. Se repite en muchos autores del Siglo de Oro y en la polémica sobre la limpieza de sangre. La expresión se remonta a Juvenal, cristianizada por san Ambrosio, san Agustín... Léase la nota a este pasaje.

$137 C N, \mathrm{I}, 149$.

138 QM, I, 18, 214. Cf. MARAVALL, J. A., Utopía y contrautopía en el Quijote, Pico Sacro, Santiago de Compostela 1976, c. 3, pp. 86-90.

$139 C P, 557-558$. "No quiero que parezcamos predicadores", dice Cipión antes de este párrafo, y al terminarlo añade Berganza: "Todo eso es predicar, Cipión amigo. -Así me lo parece a mí, y así callo". Es una alusión crítica a la estructura del Guzmán de Alfarache, en el que se mezcla "lo humano con lo divino", como se dice en el prólogo de la primera parte del Quijote.

$140 Q M$, II, 49, 1117.

$141 Q M$, I, 25, 312 .

$142 Q M$, I, 51, 631. 
Cervantes habla en varios textos sobre los cristianos viejos y sobre los conversos. Un brevísimo apunte sobre la limpieza de sangre. En 1449, los gobernantes de Toledo dieron una sentencia-estatuto en que se negaba a los conversos judíos el acceso a cualquier oficio y beneficio. El primer Colegio Universitario que estableció el Estatuto de Limpieza de Sangre fue el de san Bartolomé de Salamanca (1414), los bartolomicos. Los labradores, orgullosos de su sangre limpia frente a las otras clases, vieron que se les abría un camino seguro para ocupar altos puestos en la administración del Estado y en la Iglesia. Se lanzaron a la conquista de la riqueza, la honra y el poder. "Yo soy de limpio linaje", exclama Pedro Crespo, alcalde de Zalamea, y a su hijo le dice: "Eres de limpio linaje, / más que el sol, / pero villano. / Lo uno y lo otro te digo; / aquello, porque no humilles / tanto tu orgullo y tu brío, / que dejes, desconfiado, / de aspirar con cuerdo arbitrio / a ser más"143. Otro labrador, Períbañez, alcalde de Ocaña, le dice al rey: "Yo soy un hombre, / aunque de villana casta, / limpio de sangre, y jamás / de hebrea o mora manchada"144. Fueron muchos los villanos que llegaron a ser obispos, oidores, inquisidores, virreyes y muchísimos los que ocuparon puestos en la burocracia. Bartolomico fue Juan Martínez Silíceo, arzobispo de Toledo, que en 1546 impuso el Estatuto de Limpieza de Sangre. Cabildos, órdenes miltares, órdenes religiosas y otras muchas instituciones establecieron sus propios Estatutos. Los Estatutos se convirtieron en instrumento de luchas sociales. Varios inquisidores, el mismo Felipe II, el Duque de Lerma, el Conde-Duque de Olivares intentaron mitigarlos, pero nunca se atrevieron a legislar contra ellos. Los bartolomicos habían inundado España y controlaban las enmarañadas redes del poder. La inhabilitación y la deshonra perduraron contra la nobleza y la burguesía. Los colegios se convirtieron en coto cerrado de los cristianos viejos y se descuidaron los requisitos intelectuales ${ }^{145}$. Si a esto se añade el proceso inquisitorial

143 CALDERÓN DE LA BARCA, P., El alcalde de Zalamea, edición de Ángel ValbuenaBriones, Cátedra, Madrid 200319, v. 490 y vv. 1581-1588.

144. LOPE DE VEGA, F., Peribáñez y el Comendador de Ocaña - La dama boba, edición de Alonso Zamora Vicente, Espasa-Calpe, Madrid 19692, vv. 3032-3035.

145 CASTRO, A., "Cervantes y el Quijote a nueva luz", en Cervantes y los casticismos españoles, edic. cit., 17-143; SICROFF, A., Los Estatutos de limpieza de sangre (controversias entre los siglos XVI y XVII), Taurus, Madrid 1985; DOMÍnGUEZ ORTIZ, A., Los judeoconversos en España y América, Istmo, Madrid 1971; RÁBADE OBRADÓ, M. del Pilar, "Unir y separar: Algunos efectos socio-religiosos de la acción inquisitorial durante el reinado de Isabel I", en Arbor,178 (2004), pp. 67- 86; NETANYAHU, B., Los marranos españoles, Junta de Castilla y León, Valladolid 20002; PÉREZ FERREIRO, E., El tratado de Uceda contra los Estatutos de Limpieza de Sangre, Aben Ezra, Madrid 2000. Hay que tener muy presentes las observaciones agudas y certeras que ASENSIO, E., hizo a Castro y a Sicroff sobre los conversos en La España imaginada de Américo Castro, edic. cit., pp. 49-183. 
contra los hebraístas de Salamanca sobre los nuevos métodos exegéticos, no es de extrañar que la Universidad se despeñara por la barranca abajo de la decadencia.

Dentro de esta oposición limpieza de corazón / limpieza de sangre, se movía también fray Luis de León. Entre las cualidades de los súbditos de Cristo "casi todas ellas se reducen a esta, que es ser generosos y nobles todos y de un mismo linaje [...]. Ningún vasallo es vil en linaje ni afrentado por condición, ni menos bien nacido el uno que el otro [...]. No tener vasallos viles y afrentados". Pero a continuación dice de los reyes que se creen señores "cuando hallan mejor orden, no sólo para afrentar a los suyos, sino también para que vaya cundiendo por muchas generaciones su afrenta y que nunca se acabe, [siendo cabeza] de un cuerpo disforme y vil, [...] pastores de un ganado roñoso [...]. Dañan a su propia honra cuando buscan invenciones para manchar la de los que son gobernados por ellos [...]. No es posible que se anude con paz el reino cuyas partes están opuestas entre sí y tan diferenciadas, unas con mucha honra y otras con señalada afrenta [...]. El reino adonde muchas órdenes y suertes de hombres y muchas casas particulares están como sentidas y heridas, y adonde la diferencia, que por estas causas pone la fortuna y las leyes, no permite que se mezclen y se concierten bien unas con otras, está sujeto a enfermar y a venir a las armas con cualquiera razón que se ofrece. Que la propia lástima e injuria de cada uno, encerrada en su pecho y que vive en él, los despierta y los hace velar siempre a la ocasión y a la venganza"146. Este exaltado alegato contra los Estatutos y el espulgo de linajes puede deberse a su conciencia de converso. Pero si nos concentramos en su raça, falsearíamos su pensamiento. Ningún contenido cultural se puede explicar por la sangre o casta.

"Siervos de Cristo" se llama a los cristianos y "siervo de Dios" se llama a un sacerdote147. "Obedeciendo mejor a su Dios en ello que en otra cosa"148, Adán procuró tener hijos y perpetuar la generación humana. Al P. Cruz le han elegido superior: "Acepte y calle que así lo quiere Dios"149. Cumpliendo la palabra que había dado a Dorotea, "cumplirá con Dios"150, se le recuerda a don Fernando. De la entrada en religión se dice: "En ella asiste lo más / de cuanto a Dios satisface"151. "Si esto trae mi esposa [hermosura, honestidad y

146 LEÓN, fray Luis de, De los nombres de Cristo, edic. cit., 1. 2, Rey de Dios, pp. 374377. Cf. BATAILLON, M., Erasmo y España, edic. cit., c. 14, pp. 767-768, n 77.

147 TA, I, 118 y 119 .

$148 L G, \mathrm{IV}, 437$.

$149 R D$, III, 361 .

$150 Q M, I, 36,472$.

$151 P, 6,45$. 
buenas costumbres], yo serviré a Dios con gusto"152. A la condesa Constanza se le muere el esposo en los brazos y quiere hacer voto de ser monja, pero se le advierte: "Sedlo y no le hagáis; que las obras de servir a Dios no han de ser precipitadas, ni que parezcan que las mueven accidentes, y éste de la muerte de vuestro esposo quizá os hará prometer lo que después o no podréis o no querréis cumplir"153. Al llegar a Lisboa -estamos ya en tierras católicas, "tierra de promisión"-, dice Antonio: "Ahora sabrás, bárbara mía, del modo que se ha de servir a Dios"154. Luscinda pide a un transeúnte que lleve una carta urgente a Cardenio "y en ello haréis un gran servicio a Nuestro Señor"155. Lotario le recuerda a su amigo Anselmo que "las cosas dificultosas se intentan por Dios" [santidad], "por respeto del mundo" [riquezas] y "por Dios y por el mundo juntamente" [guerra] ${ }^{156}$. Carrizales piensa volver a su tierra, "dar en ella su hacienda a tributo" [comprar tierras o censos], "dando a Dios lo que podía, pues había dado al mundo más de lo que debía"157. Dar a Dios de su hacienda es dar a la Iglesia mandas y limosnas. Con ellas se buscaba la salvación a través de las oraciones, especialmente de los religiosos. Así se construyeron muchos monasterios y capillas. Las guerras de religión son un gran servicio a Dios. Las mujeres de Orán piden que se revoque la orden de enviarlas a España, junto con los viejos y los niños, ante un combate próximo, "que en ello harás a Dios servicio grande", "porque piensan / por Dios y por su ley y por su patria / morir sirviendo a Dios"158. El cautivo sigue "el ejercicio de las armas, sirviendo en él a Dios y a mi rey"159. "No hay otra cosa en la tierra más honrada ni de más provecho que servir a Dios, primeramente, y luego a su rey y señor natural, especialmente en el ejercicio de las armas"160. Don Quijote ve unos molinos de viento, que toma por "desaforados gigantes", y se dispone a entrar en guerra con ellos, "que ésta es buena guerra, y es gran servicio de Dios quitar tan mala simiente [estirpe] de sobre la faz de la tierra"161. Los gigantes aparecen siempre como enemigos de los hombres en la Biblia, en la mitología, en los libros de caballerías o en el folclore. Luchar contra ellos es

152 FS, 319

153 PS, III, 9, 523 .

$154 P S$, III, 1,432 .

$155 Q M, \mathrm{I}, 27,338$.

${ }_{156} Q M, \mathrm{I}, 33,419$.

$157 C E, 330$. No creo que aquí se aluda al pasaje de "dar al César lo que es del César y a Dios lo que es de Dios" (Mt 22, 21 par), como anota el editor. Esto era frecuente en el Siglo de Oro: primero se sirve al mundo y al final se hace uno muy devoto y se da a la Iglesia dineros para que rece por su ánima.

$158 \mathrm{GE}, \mathrm{I}, 191$.

159 QM, I, 39, 495.

$160 \mathrm{QM}, \mathrm{II}, 24,910$.

${ }^{161} Q M, \mathrm{I}, 8,103$. 
guerra justa, y en ella era lícito quedarse con el botín. Caballero y escudero, "Sancho el bueno", sirven a Dios en su misión: "Dios, que es proveedor de todas las cosas, no nos ha de faltar, y más andando tan en su servicio como andamos"162. El canónigo aconseja a don Quijote dedicarse a otras lecturas "y todo esto, para honra de Dios, provecho suyo y fama de la Mancha"163. Sancho pide que se vaya Pedro Recio. "Si no, tomaré esta silla donde estoy sentado y se la estrellaré en la cabeza; que yo me descargaré con decir que hice servicio a Dios en matar a un mal médico, verdugo de la república"164. Si la virtud es servicio de Dios, el pecado es deservicio. "Cuando te convidaren a hacer ofensas que redunden en deservicio de Dios, no tienes para qué armar el arco, ni decir injuriosas palabras" 165 .

\section{JESUCRISTO}

\subsection{Los misterios de la vida de Cristo}

En el resumen que los penitenciarios hacen de la fe, Cristo ocupa el lugar central en importancia y extensión. El amor de Cristo a los hombres es la razón de la encarnación. Cervantes recuerda los trabajos, los sufrimientos de Cristo según las consideraciones usuales en la época. "Los trabajos de Jesús" es el título de la obra de fray Tomé de Jesús, agustino portugués, prisionero con otros muchos en la batalla de Alcazarquivir, donde perdió la vida el rey don Sebastián de Portugal. Cervantes no se olvida de Cristo triunfante y glorioso sobre el que la muerte ya no tiene dominio.

"Jesucristo, Dios y hombre verdadero"166. La Virgen es "la esposa / que al sacro Verbo limpia carne distes"167. "Ya en las empíreas sacrosantas salas / el paraninfo alígero se apresta / o casi mueve las doradas alas / para venir con la embajada honesta: / que el olor de virtud que de ti exhalas, / Virgen bendita, sirve de recuesta / y apremio a que se vea en ti muy presto / del gran poder de Dios echado el resto"168. Tomás Rodaja visita el santuario de Nuestra Señora de Loreto: "Vio el mismo aposento y estancia donde se relató la más alta embajada y de más importancia que vieron, y no entendieron, todos los cie-

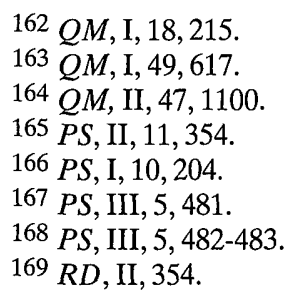


los, y todos los ángeles y todos los moradores de las moradas sempiternas". "A Cristo crucificado / os doy por fiador también; / dóyosle niño en Belén, / perdido y después hallado"169. "Discurrieron por el misterio sagrado y amoroso de la Encarnación [...]. Contaron cómo convino que la segunda persona de las tres, que es la del Hijo, se hiciese hombre [...]. Mostráronle la muerte de Cristo, los trabajos de su vida, desde que se mostró en el pesebre hasta que se puso en la cruz [...]. Mostráronle asímismo a Jesucristo, Dios vivo, sentado a la diestra del Padre [...]. Aseguráronle infaliblemente la venida deste Señor a juzgar el mundo sobre las nubes del cielo" 170 .

\subsection{Jesucristo Maestro, Legislador y Pastor}

El título de Maestro es uno de los fundamentales de Jesucristo. La paz "es el mayor bien que los hombres pueden desear en esta vida. Y, así, las primeras buenas nuevas que tuvo el mundo y tuvieron los hombres fueron las que dieron los ángeles la noche que fue nuestro día, cuando cantaron en los aires: Gloria sea en las alturas, y paz en la tierra a los hombres de buena voluntad; y a la salutación que el mejor maestro de la tierra y del cielo enseñó a sus allegados y favoridos [favorecidos] fue decirles que cuando entrasen en alguna casa dijesen: Paz sea en esta casa; y otras muchas veces les dijo: Mi paz os doy, mi paz os dejo; paz sea con vosotros, bien como joya y prenda dada y dejada de tal mano, joya que sin ella en la tierra ni en el cielo puede haber bien alguno. Esta paz es el verdadero fin de la guerra"171. Cervantes ama la paz, pero no es erasmista. La batalla de Lepanto, donde perdió el uso de la mano izquierda, fue "la más memorable y alta ocasión que vieron los pasados siglos, ni esperan ver los venideros"172. En varios textos llama a la guerra contra el turco, aunque se siente decepcionado por la política de Felipe II. Los ideales por los que él luchó en Lepanto ya no significaban nada. El trato de Argel y El cerco de Numancia son una exaltación de la guerra. Escribió otra

$170 \mathrm{PS}, \mathrm{IV}, 5,657-658$. Dejo fuera todos los textos referentes a las fiestas litúrgicas de Jesucristo. Sobre este símbolo, cf. VEGA, J., "La fe en Cervantes", en Religión y Cultura, 52 (2006), pp. 36-44.

${ }_{171} Q M, \mathrm{I}, 37,485-486$. Se recuerda a Aristóteles: "El fin de la guerra es la paz" (Política, IV, XV, 1334a15). y se traducen las palabras del Evangelio de San Lucas $(2,14)$, con las que comienza el Gloria de la misa. Sobre este tema de la guerra y de la paz, cf. MARAVALL, J. A., Utopía y contrautopía en el Quijote, edic. cit., c. 6, pp. 209-213.

${ }^{172} N E$, prólogo, 17. $Q M$, II, prólogo al lector, 673: "Si mi manquedad hubiera nacido en alguna taberna, sino en la más alta ocasión que vieron los siglos pasados, los presentes, ni esperan ver los venideros". 
comedia perdida titulada La batalla naval (Lepanto). Cervantes "sostiene sobre la guerra la doctrina comúnmente aceptada por los teólogos en la Europa de su tiempo"173.

Cristo es "el mejor maestro de la tierra y del cielo". Habrá que acudir a su palabra, leer la Biblia, y no contentarse con las enseñanzas de los que prohiben leerla. Cervantes la conocía bien. Imitemos, pues, a san Pablo, "a quien sirvieron de escuelas los cielos y de catedrático y maestro que le enseñase el mismo Jesucristo"174. Algo parecido se dice de santa Teresa, aunque referido a Dios: "Y siendo tu maestro, te levanta / al cielo, que señala por tu escuela"175. Dice un morisco: "Ay, cuándo llegará el tiempo [...], donde se verá España de todas partes entera y maciza en la religión cristiana, que ella sola es el rincón del mundo donde está recogida y venerada la verdadera verdad de Cristo"176. Aquí Cervantes no juega limpio, al poner en boca de un morisco, lo hace también en el Quijote, la justificación de las razones por las que se los expulsó.

Cristo es también Legislador: "El tomar venganza injusta, que justa no puede haber alguna que lo sea, va derechamente contra la santa ley que profesamos, en la cual se nos manda que hagamos bien a nuestros enemigos, y que amemos a los que nos aborrecen, mandamiento que aunque parece algo dificultoso de cumplir, no lo es sino para aquellos que tienen menos de Dios

173 Morón, C., Para entender el Quijote, edic. cit., c. 10, p. 312. Blasco, J., Cervantes: un hombre que escribe, edic. cit., c 15, pp. 221-227, siguiendo a Barbara Simerka, niega que en La Numancia exista la ideología oficial, nacionalista y católica. Los españoles de 1580, también Felipe II, "visorrey de Dios en todo el suelo", eran los herederos de los numantinos según el texto de la "Profecía del Duero". Eran las víctimas. Pero las glorias militares, logradas a costa de muchas vidas humanas, eran las mismas que las de Cipión, el general de los romanos. Eran, a un mismo tiempo, verdugos. ¿No pensarían los lectores y los espectadores en casos similares a los de Numancia, que colocaban a Felipe II en el papel de Cipión? Cervantes estaría jugando, como siempre, a la ambigüedad. Se me hace muy difícil aceptar esta interpretación. No sé lo que pensaría Cervantes, pero sí sé que el sentimiento nacionalista, el orgullo nacional, no funciona así. Cualquier pueblo que es invadido condena a los invasores como criminales y exalta a los héroes que resisten y a las ciudades que se enfrentan hasta perecer abrasadas; pero si ese mismo pueblo se convierte en invasor hasta lograr un Imperio, a los que se ensalza es a los conquistadores y a las víctimas se las hunde aún mas. Los españoles han estado siempre orgullosos de Numancia, de Viriato, hasta de Istolacio e Indortes, y, a la vez, orgullosos de los conquistadores de América y de los misioneros, a los que no hay nada que reprocharles: llevaron la fe católica y la cultura. Todavía funcionó así el último centenario del descubrimiento de América. Los conquistadores han sido siempre opresores y todos los Imperios se han forjado a sangre y fuego. Estamos aún muy lejos de considerar a las vícimas protagonistas de la historia y cambiar nuestra visión de la realidad.

$174 Q M$, II, 58, 1198. Interpretar este texto, como hace Castro, como protesta contra la limpieza de sangre es pasarse de rosca. Léase el comentario de MORREALE, M., a este capítulo en el volumen complementario, en el apartado Lecturas del Quijote, pp. 210-215.

$175 P, 25,52$.

176 PS, III, 11, 547-548. 
que del mundo y más de carne que de espíritu; porque Jesucristo, Dios y hombre verdadero, que nunca mintió, ni pudo ni puede mentir, siendo legislador nuestro, dijo que su yugo era suave y su carga liviana, y, así, no nos había de mandar cosa que fuese imposible el cumplirla"177.

Antonio, católico español, instruye a su mujer Ricla, bárbara, en la fe cristiana. Ella hace un resumen de esa fe, una especie de símbolo, y entre otras cosas dice: el papa, sucesor de san Pedro, "su primer pastor después de Jesucristo, primero y universal pastor de su esposa, la Iglesia"178. Ricla espera "el día que ha de ser tan dichoso que nos saque desta prisión y nos lleve adonde, con libertad y certeza, y sin escrúpulo, seamos unos de los del rebaño de Cristo, en quien adoro en aquella cruz que allí veis"179. "A Ti, Pastor bendito, que buscaste / de las cien ovejuelas la perdida, / y, hallándome del lobo perseguida, / sobre tus hombros santos te la echaste; / a Ti me vuelvo en mi aflicción amarga, / y a Ti toca, Señor, el darme ayuda, /que soy cordera de tu aprisco ausente"180. "Moradores del cielo, [...] pedid al gran Pastor de los rebaños / del cielo y de la tierra que no deje"181 que lleve Satanás el alma de doña Ana. Un padre cautivo de los moros habla a sus hijos pequeños, también cautivos, que "vienen vestidos a la turquesa de galanes": "¿Qué se hizo el traje / que mostraba en mil semejas / que érades de Cristo ovejas, / aunque de pobre linaje"182. Sus hijos no han podido evitar que los vistan de turcos, pero morirán mártires.

\subsection{Jesucristo Redentor}

Creación del primer hombre en el Paraíso, caída en el pecado original, castigo, redención por Jesucristo. Eran cuatro momentos importantes en la

$177 Q M$, II, 27, 939. "Hacer bien a los enemigos...". En $Q M$, I, prólogo, 15, se cita la primera parte del versículo en latín. Cf. Mt 5, 44; Lc 6, 35. "Su yugo era suave...", cf. Mt 11, 30. "Más de carne que de espíritu". La contraposición entre carne y espíritu está en varios textos de san Pablo: Rom 8, 5-6.9; Gal 3,3; 5, 16-17; 6, 8. Léanse las notas a este pasaje. En la alocución pacifista del guerrero don Quijote se ha señalado la huella de Erasmo y el ideal ético del perdón. Cf. ARELLANO, I., en el volumen complementario, en el apartado Lecturas del Quijote, p. 157. Pero Cervantes está muy alejado del pacifismo erasmista y la idea del perdón no es exclusiva de Erasmo. Bataillon aproxima esta idea de "yugo suave" a la doctrina expuesta por Juan de Valdés en su Diálogo de la doctrina cristiana. Se podrían citar muchos autores espirituales, pero ¿influyeron realmente en Cervantes? Un lector de la Biblia como Cervantes no necesitaba intermediarios.

178 PS, I, 6, 176. Cf. Jn 10, 1-16.

$179 \mathrm{Ib}, 178$.

180 GS, I, 377.

$181 R D$, II, 354.

182 BA, II, 294. 
historia de la salvación. A ellos se atiene Cervantes. La Redención (muerte y resurrección de Jesucristo) es el artículo principal de la fe cristiana. "Y así fundado éste, está fundada toda la religión; porque lo que hace más dificultad al sentido del hombre es la cruz de Jesucristo, y entender el hombre que en ella y en el que se puso en aquel palo por nosotros consiste nuestra salvación, y que no hay otro remedio para salvarse los hombres que el remedio de la cruz [...]. Este es el artículo principal que hace al hombre en sustancia cristiano. Este es donde se prueba nuestra fe. Este es el toque suyo: poner la salud y el remedio en un hombre crucificado y justiciado por malo"183. Añade Carranza: "Estos dos misterios (muerte y resurrección) andan siempre juntos, y no uno sin otro; porque ambos juntos obraron nuestra redención y nuestra salud, y no uno sin otro. Si faltara uno, no fuera hecho nada"184.

Lucifer se queja: "Y no contento aquél que dio en un palo / la vida, que fue muerte de la muerte, / de verme despojado del regalo / de mi primera aventajada suerte"185. El diablo venció en el Paraíso e hizo esclavos a los hombres. En la cruz Cristo le derrotó, devolviéndoles la libertad. Esta teoría está presente en este otro texto: "Moradores del cielo, [...] pedid al gran Pastor de los rebaños / del cielo y de la tierra que no deje / que lleve Satanás esta ovejuela / que Él almagró con su preciosa sangre" 186 . No es difícil ver en estas palabras una alusión al episodio del ángel exterminador (Ex 12, 1-14), que pasa de largo ante las puertas teñidas con la sangre del cordero pascual. Las almas están teñidas con la sangre de Cristo, almagradas, señaladas como propiedad suya, sustraídas a Satanás, que ya no tiene ningún derecho sobre ellas.

Estamos ante la teoría de los derechos del diablo. Los gnósticos, entre ellos Marción, sostenían que el hombre estaba en poder del Demiurgo. Cristo, enviado por el Padre, le rescató pagando con el precio de su sangre. Esto entró en la teología y en la mentalidad popular, cambiando al demiurgo por el demonio. No hay más textos de Cervantes sobre los derechos del demonio y no es extraño que los dos estén en una obra claramente contrarreformista.

Cristo anuló y clavó en la cruz el quirógrafo que nos era contrario (Col 2, 14-15), dice Carranza. "Y quitando este derecho que tenía el diablo con nosotros, nos libró a nosotros de su poder, donde por nuestros pecados éramos prisioneros, y despojó estos príncipes tiranos de la presa que tenían hecha; y siendo vencedor de los potentados del infierno, triunfó de ellos pú-

183 CARRANZA DE MIRANDA, B., Comentario sobre el catecismo christiano, BAC, Madrid 1972, t. I, pp. 215-216.

184 ÍD., ib., t. I, p. 267.

${ }^{185} R D$, III, 361 . No cito los textos referentes a la devoción a la cruz y al Crucificado, que deben ir entre las muchas devociones que aparecen en sus obras.

$186 R D$, II, 354 
blicamente en la cruz, como lo suelen hacer los vencedores de los vencidos. $\mathrm{Y}$ no queda cosa por donde los demonios nos puedan poner demandas delante la justicia divina"187. "Nos rescató de la tiranía del demonio"188. "No es difícil ver al diablo vencido cuando resucitó al que quitó la vida. Ver al diablo vencido cuando parecía vencedor, al morir Cristo, es un misterio mayor y más profundo de entender. Entonces la sangre del que no había cometido ningún pecado fue derramada para remisión de los nuestros, de modo que a los que el diablo con derecho esclavizaba como reos de pecado en su condición mortal, en justicia los tuvo que dejar libres por Cristo, a quien, inocente de todo pecado, condenó a muerte sin merecerlo. Vencido por la justicia y atado el fuerte con estas cadenas, arrebatándole sus vasos, que en su poder y en el de sus ángeles eran vasos de ira, los convirtió en vasos de misericordia" 189.

Cristo nació para salvarnos, para perdonar nuestros pecados. "Pues nació para salvarme / Dios, y en cruz murió enclavado, / perdonará mi pecado"190. "A Ti me vuelvo, gran Señor, que alzaste / a costa de tu sangre y de tu vida / la mísera de Adán primer caída, / y adonde él nos perdió Tú nos cobraste"191. El cristiano no debe olvidar que ha sido comprado a precio de la sangre de Cristo. En los momentos difíciles de su vida debe encontrar en la cruz de Cristo su arrimo, palabra de tanto arraigo en el vocabulario de san Juan de la Cruz. "Aurelio, paso, / que no es de caballero lo que piensas, / sino de mal cristiano, descuidado / de lo que a Cristo y a su sangre debe"192. "Y ¿no sabes también que aquel arrimo / con que el cristiano se levanta al cielo / es la cruz y pasión de Jesucristo, / en cuya muerte nuestra vida vive?"193. "¿Alma tenéis los cristianos? / -Sí; y tan ricas y extremadas / cuanto por Dios rescatadas"194.

En el Persiles hay dos textos sobre la Redención, en los que Cristo da a Dios una satisfacción infinita. "Hoy comenzó a romperse la cadena / del hiero antiguo [...]. De nuestra muerte vida, / pues vos fuistes el medio conveniente / que redujo a pacífica concordia / de Dios y el hombre la mortal dis-

187 CARRANZA DE MIRANDA, B., Comentario sobre el catecismo christiano, edic. cit., t. I, p. 244.

188 Catecismo romano, edición de Pedro Martín Hernández, BAC. Madrid 1956, I, IV, pp. 14,128 .

189 SAN Agustín, La Trinidad 13, 15, 19.

$190 R D$, II, 351.

191 GS, II, 377.

192 TA, III, 134.

193 TA, IV, 140.

$193 \mathrm{TA}, \mathrm{IV}, 140$

$194 T A, \mathrm{I}, 114$. 
cordia. / La justicia y la paz hoy se han juntado / en vos, Virgen santísima, y con gusto / el dulce beso de la paz se han dado, / arra y señal del venidero Augusto. / [...] De la borrasca antigua, la bonanza. / [...] Sois la Esposa / que al sacro Verbo limpia carne distes, / por quien de Adán la culpa fue dichosa; / sois el brazo de Dios que detuvistes / de Abrahán la cuchilla rigurosa, / y, para el sacrificio verdadero, / nos distes al mansísimo Cordero. / Creced, hermosa planta, y dad el fruto / presto en sazón, por quien el alma espera / cambiar en ropa rozagante el luto / que la gran culpa le vistió primera. / De aquel inmenso y general tributo / la paga conveniente y verdadera / en vos se ha de fraguar; creed, Señora, / que sois universal remediadora. / [...] Se vea en Ti.muy presto / del gran poder de Dios echado el resto"195. "Dichosa del cielo puerta, / que levantó la caída / y resucitó la vida / de nuestra esperanza muerta"196, se ruega a la Virgen.

Se recuerdan las consecuencias del pecado original: esclavitud, discordia entre el hombre y Dios, sometidos a la tempestad, muerte, vestidos de luto, obligados como vasallos a pagar tributo al Dios soberano, pero incapaces de poder hacerlo. Todo esto lo remediará la Virgen dándonos a Jesucristo, que con su sacrificio pagará por nosotros, y nos hará libres rompiendo "la cadena del hierro antiguo", y nos devolverá "la concordia" con Dios y la paz y la justicia y la bonanza, y nos vestirá de "ropa rozagante". "Arra y señal" tienen aquí un mismo significado: es una reduplicación. Se compara a Jesucristo con Augusto, que trajo "la paz a todo el orbe", como dice la calenda de Navidad.

¿Cómo es posible llamar "dichosa" a la culpa de Adán? Fray Luis de León con algunos otros teólogos razona que todas las maravillas de la creación se hicieron para producir un Fruto, la Encarnación del Verbo ${ }^{197}$; pero no era ésta la teoría más común. Fue el pecado de Adán el que exigió que el Verbo se encarnara para dar a Dios una satisfacción infinita. "Si el hombre no hubiese perecido, el Hijo del hombre no habría venido"198. "Cómo las tres personas divinas miraban toda la planicia o redondez de todo el mundo llena de hombres, y cómo viendo que todos descendían al infierno, se determina en

195 PS, III, 5, 480-482. Es asombrosa la cantidad de citas bíblicas en esta poesía a la Virgen. El editor señala bastantes, pero aún quedan algunas más. En la n. 31 de la p. 481, el editor sostiene que Cervantes, al citar a Augusto, tiene presente la Égloga IV de Virgilio, que los cristianos interpretaron como profecía del Mesías (Lactancio, san Agustín, Constantino...). Pero en esa Égloga no aparece Augusto. En ella se habla de un niño que va a nacer, quizá un hijo del cónsul Polión, al que va dedicada. Durante su vida surgirá una nueva Edad de Oro.

$196 R D$, II, 352. 179-182.

197 Luis de LEÓn, fray Luis de, De los nombres de Cristo, edic. cit., 1. 1, Pimpollo, pp.

198 SAN AgUSTín, Sermón 174, 2. 
la su eternidad, que la segunda persona se haga hombre, para salvar el género humano"199. La culpa de Adán fue "feliz" porque por ella se encarnó el Hijo de Dios. "Necesario fue el pecado de Adán, que ha sido borrado por la muerte de Cristo. ¡Feliz la culpa que mereció tal y tan grande Redentor!", se canta en el pregón de la Vigilia Pascual.

Los penitenciarios "contaron cómo convino que la segunda persona de las tres, que es la del Hijo, se hiciese hombre, para que, como hombre, Dios pagase por el hombre y Dios pudiese pagar como Dios; cuya unión hipostática sólo podía ser bastante para dejar a Dios satisfecho de la culpa infinita cometida, que Dios infinitamente se había de satisfacer y el hombre, finito, por sí no podía, y Dios, en sí sólo, era incapaz de padecer; pero, juntos los dos, llegó el caudal a ser infinito, y así lo fue la paga" 200 .

Imitando a Cristo, el P. Cruz entrega sus méritos y se compromete a pagar por lo pecados de doña Ana: "Al alma de doña Ana de Treviño, / que está presente, doy de buena gana / todas las buenas obras que yo he hecho / en caridad y en gracia. / [...] Y, en contracambio, tomo sus pecados, / por enormes que sean, y me obligo / de dar la cuenta de ellos en el alto / y eterno tribunal de Dios eterno / y pagar los alcances [cantidad que no puede pagar] y las penas / que merecieron sus pecados todos"201. Doña Ana se arrepiente, se confiesa, recibe los sacramentos y muere, "dejando la cárcel de su cuerpo estrecha" y volando su alma "a las regiones refulgentes". "En esa misma feliz hora / se vio del padre Cruz cubierto el rostro / de lepra, adonde el asco mismo mora"202. Es lo que hasta fechas bien recientes se llamaba ofrecerse a Dios como víctima en holocausto.

199 San IGNACIO DE LOYOLA," Ejercicios espirituales", en Obras completas, edic. cit., $\mathrm{n}^{\circ} .102, \mathrm{p} .181$.

200 PS, IV, 5, 657. Carlos Alberto Moreyra dice que "para ciertos socinianos Cristo es sólo un hombre a quien Dios creó y confirió sobrenatural poder y de quien se valió como medio para la creación del mundo. Cabría sospechar, con mucha lógica, que el pasaje que estudiamos pretende insinuar con disimulo este concepto" (cit. por el editor, Apéndices, XXXIII, p. 748, opinión que no comparte). Añade que la historia eclesiástica supone que el Concilio de Trento uniformó las creencias en el campo católico. "La historiografía secreta de Cervantes contradice este supuesto". Añade todavía más: muchos católicos seguían secretamente la justicia imputada luterana, convencidos de que el mismo papa la seguía. ¡Ahí es nada! Todo esto se afirma sin aducir una sola razón. ¿Cómo es posible concluir de la doctrina de Cervantes sobre Cristo que éste es sólo hombre? Es verdad que los que no estamos iniciados en "la historiografía secreta de Cervantes" no entendemos nada. Alguien nos tendría que iniciar. Cf. VEGA, J., "La fe en Cervantes", en Religión Cultura, 52 (2006), pp. 40-41.

$$
\begin{aligned}
& 201 R D, \text { II, } 354 . \\
& 202 R D, \text { III, } 355 .
\end{aligned}
$$


Los derechos del demonio y la satisfacción infinita a Dios aparecen en este texto de fray Luis: "Con sólo permitir que el demonio pusiese a un hombre en la cruz y le diese allí muerte, trujo a felicísimo efecto todas las cosas que arriba dije juntas y enteras. Porque verdaderamente fue así, que sólo el morir Cristo en la cruz, adonde subió por su permisión, y por las manos del demonio y de sus ministros, por ser persona divina la que murió, y por ser la naturaleza humana en que murió inocente y de todo pecado libre, y santísima y perfectísima naturaleza, y por ser naturaleza de nuestro metal y linaje, y naturaleza dotada de virtud general y de fecundidad para engendrar nuevo ser y nacimiento en nosotros, y por estar nosotros en ella por esta causa como encerrados, así que aquella muerte, por todas aquestas razones y títulos, conforme a todo rigor de justicia, bastó por toda la muerte a que estaba el linaje humano obligado por justa sentencia de Dios, y satisfizo, cuanto es de su parte, por todo el pecado, y puso al hombre, no sólo en libertad del demonio, sino también en la inmortalidad y gloria y posesión de los bienes del Dios. Y porque puso el demonio las manos en el inocente, [...] perdió justísimamente el vasallaje que sobre los hombres por su culpa dellos tenía, y le fueron quitados como de entre las uñas mil queridos despojos, y él mereció quedar por esclavo sujeto de aquél que mató. [...] Y el que mala y engañosamente al sencillo y flaco hombre, prometiéndole bien, había hecho su esclavo, es agora pisado y hollado del hombre, que es ya su señor por el merecimiento de la muerte de Cristo"203.

Hay en estos textos mucho que comentar. La idea de la muerte de Cristo como "satisfacción" a Dios por nuestros pecados aparece en Tertuliano y después en san Ambrosio de Milán. Pero fue san Anselmo de Canterbury (siglo XI) el que elaboró detenidamente esta teoría, seguida después por los teólogos y predicada al pueblo cristiano. Parte de un principio jurídico que venía del derecho romano y del derecho germánico y que tenía plena vigencia en la sociedad estamental de la Edad Media: el honor está en el que honra, la injuria en el injuriado. Un inferior no puede honrar al que sea superior a él; en cambio, éste sí puede honrar a áquel. La ofensa será tanto más grave cuanto sea la calidad de la misma y el lugar que ocupe en la jerarquía social el ofendido. Las ofensas estaban tarifadas atendiendo a estos dos aspectos. La tarifa se llamaba caloña (calonia, calumnia) ${ }^{204}$. Don Quijote se gloría de ser

${ }^{203}$ LEÓN, fray Luis de, De los nombres de Cristo, edic. cit., 1. II, Brazo de Dios, pp. 346347.

204 Cf. LAPESA, R., Léxico hispánico primitivo (siglos VIII al XII), edic. cit., s.v. calonia; VALDEAVELlano, L. G. de, Historia de las instituciones españolas (de los orígenes al final de la Edad Media), Revista de Occidente, Madrid 1968, passim, en especial pp.440-441. 
"hidalgo de devengar quinientos sueldos" 205 , de tener derecho en caso de una injuria a una compensación de "quinientos sueldos".

Adán con su pecado ofendió a Dios, que es infinito, infinitamente. Ningún hombre puede darle satisfacción. "Los que reciben son inferiores a los que dan, y así es Dios sobre todos, porque es dador sobre todos, y no pueden corresponder las dádivas del hombre a las de Dios con igualdad, por infinita distancia"206. De ahí la necesidad de la Encarnación, del cur Deus homo, de por qué Dios se hizo hombre. Siendo hombre, podía asumir los pecados de todos, y, siendo Dios, podía dar una satisfacción infinita. Las expresiones de san Anselmo son irritantes y furibundas. Dios impulsó, arrastró a su Hijo a la muerte como chivo expiatorio y se deleitó en su sangre. Es un ajuste de cuentas entre Dios y Dios ${ }^{207}$. Es un Dios celoso, justiciero, cruel y vengativo, que sólo tiene en cuenta su honor. Su amor, su bondad y su misericordia están totalmente ausentes. Esta es la teoría que se ha mantenido durante siglos. La sigueron los teólogos, triunfó en los autores espirituales, en los penitenciales y devocionarios y en los predicadores. ¡Cómo se entusiasmaban los grandes predicadores viendo a Dios descargar sus rayos y truenos sobre esta víctima tanto tiempo esperada! En el resistero del Viernes Santo, Dios abrevó su cólera en la sangre de su Hijo hasta quedar aplacado. ¿Aplacado? La cólera de Dios sigue descargando y descargando contra los pecadores hasta el día del juicio final, en que dará a cada uno su merecido. Todavía anda por ahí una canción en la que se suplica a Dios: "No estés eternamente enojado". ¡Qué horror! ¿Se dan cuenta de lo que están diciendo los que la cantan? Y si es así, ¿no se les revuelven las entrañas ante esta blasfemia? Es difícil encontrar insultos y calumnias más graves contra Dios y Jesucristo. Una vez más hay que agradecer a Cervantes su contención y sobriedad. No hay que olvidar que estamos en la época de la Contrarreforma, donde sobreabundaban los excesos, especialmente cuando se hablaba de la muerte de Cristo y de su sangre redentora, y, como consecuencia de ello, la exaltación del sufrimiento en la vida cristiana para asemejarse al dolor de Cristo y aumentar el caudal de méritos para el Cielo. ¡Culto al dolor por el dolor mismo!

Pero todo esto pertenece ya a un mundo teológicamente lejano. Desde el Concilio Vaticano II todo ha cambiado. "Uno tiene la impresión de que todo eso es pura ficción. Se da a escondidas, con la mano izquierda, lo que recibe solemnemente la mano derecha. [...] Con temor nos apartamos de una

${ }^{205} Q M, \mathrm{I}, 21,254$. Léase la nota a este pasaje.

$206 Q M$, II, 58, 1205.

207 Las citas de san Anselmo en CASTILlo, J. M.., Victimas del pecado, edic. cit., c. 6, pp. $146-150$. 
justicia cuya oculta ira hace increíble el mensaje del amor. Esta concepción se ha difundido tanto cuanto falsa es. La Biblia no nos presenta la cruz como pieza del mecanismo del derecho violado; la cruz, en la Biblia, es más bien expresión del amor radical que se da plenamente, acontecimiento que es lo que hace y que hace lo que es; expresión de una vida que es ser para los demás. La teología bíblica de la cruz supone una revolución en contra de las concepciones de expiación y redención de la historia de las religiones no cristianas, pero no debemos negar que la conciencia cristiana posterior la ha neutralizado y muy raramente ha reconocido todo su alcance"208. En el Nuevo Testamento no es el hombre el que se acerca a Dios, sino Dios el que se acerca al hombre y le ofrece su amor. Dios no espera a que los pecadores expíen sus pecados. Es Él el que les sale al encuentro y los reconcilia (2 Cor 5, 19).

Las expresiones de la fe no están fijas para siempre en un cielo inmóvil, sino que se van creando según la sensibilidad y las mentalidades de las distintas épocas. $\mathrm{Y}$ unas pasan raudas, otras se mantienen siglos y siglos; pero llega un momento en que se vuelven toscas, incapaces de expresar las nuevas experiencias. Ha surgido otro mundo, y la fe tiene que buscar nuevas expresiones o dar nuevos significados a las palabras de siempre. El significado de la palabra "redención" hay que leerlo, a la luz de la historia, desde las distintas perspectivas en que escribieron los autores que reflexionaron sobre el encuentro entre Dios y el hombre. Jesucristo no murió, le mataron. ¿Por qué le crucificaron? ¿En qué subvirtió el orden social, religioso y político, para que las autoridades, tanto religiosas como civiles, le crucificaran? La cruz fue la expresión máxima de su amor incondicional y gratuito (Jn 15, 13). La palabra "redención" "significa hoy para nosotros el amor inagotable de Dios, que se inclina sobre nuestra miseria y mantiene contra viento y marea su alianza con nosotros"209, con la humanidad entera.

\subsection{La imitación de Jesucristo}

La imitación de Cristo se recuerda en ambientes de martirio. Los cristianos cautivos de los moros tienen que estar dispuestos a dar su vida por Cristo. Dice Hazén: "¿Eres cristiano? -Sí soy; / y en serlo tan firme estoy, / que deseo, como has visto, / deshacerme y ser con Cristo, / si fuese posible, hoy"210. Dice un niño,

208 RATZINGER, J., Introducción al cristianismo, edic. cit., c. 2, pp. 244-245.

209 DelumeAU, J., Guetter l'aurore. Un christianisme pour demain, edic. cit., c. 5, p. 126.

$210 B A$, I, 287. Cf. Flp 1, 23. 
atado a una columna, a punto de ser mártir, a su padre: "¿No me quieren desatar, / para que pueda, siquiera, / como es costumbre expirar?". Le contesta el padre: "No; que de aquesa manera / más a Cristo has de imitar. / Si vas caminando al cielo, / no has de sentarte en el suelo; / más ligero vas así"211. "Atado está a una columna, / hecho retrato de Cristo, / de la cabeza a los pies / en su misma sangre tinto"212. Un mártir muere a fuego lento. "Si alguna vez hablaba, / en el aire resonaba / el eco o nombre de Cristo"213. Dice una madre a su hijo: "Hijo, no las amenazas, / no los gustos y regalos, / no los azotes y palos, / [...] te mueva a dejar a Cristo / por seguir al pueblo moro"214. Renegar es hacerse "de Cristo enemigo" 215 .

Se recuerda también la imitación de Cristo, vestirse de Jesucristo, en la vida religiosa. "Se despoja el hombre viejo / para vestirse del nuevo. / Cual prudente sierpe ha sido, / pues, con nuevo corazón, / en la piedra de Simón / se deja el viejo vestido"216. La serpiente y el águila se usaban con frecuencia como imágenes cuando se hablaba de despojarse del hombre viejo y vestirse del nuevo. "Como vemos que renueva / el águila real la vieja y parda / pluma, y con otra nueva / la detenida y tarda / pereza arroja, y con subido vuelo / rompe las nubes y se llega al cielo; / tal, famoso Padilla, / has sacudido tus humanas plumas [para llegar "con nuevo vuelo al alto asiento" del Cielo]. / Que pues es tu Parnaso / el monte del Calvario, y son tus fuentes / de Aganipe y Pegaso / las sagradas corrientes / de las benditas llagas del Cordero, / eterno nombre de tu nombre espero"217. No he encontrado ningún otro texto en Cervantes sobre las llagas de Jesucristo, pero en los siglos XVI y XVII había una gran devoción. Dicen unas almas del purgatorio en la muerte del P. Cristóbal de la Cruz: "Cuando en libertad vivía, / de nosotras se acordaba, / y el rosario nos rezaba / con devoción cada día; / y cuando en la religión / entró, como habemos visto, / muerto al diablo y vivo a Cristo, / aumentó la devoción" 218 . El rufián Lugo rezaba el rosario por las almas del purgatorio. Al hacerse dominico, aumentó su devoción por ellas. No se olviden las devociones que se practicaban en el patio de Monipodio, en especial por las ánimas benditas ${ }^{219}$. ¿Ironía contra la sociedad hipócrita española? Una religiosa dice: "Yo, señor mío,

$211 B A$, III, 313-314.

$212 B A$, III, 310 .

$213 T A, \mathrm{I}, 120$.

$214 T A$, II, 124.

$215 G E$, II, 206 y 208. Sobre los mártires y los renegados, cf. VEGA, J., "La fe en Cervantes", en Religión y Cultura, 52 (2006), pp. 65-92.

$216 P, 6,45$. Alude al cambio de Simón en Pedro (Jn 1, 42; Mc 3, 16 par). La piedra de Simón es la piedra de la Iglesia (Mt 16,18).

$217 P, 7,46$

$218 R D$, III, 362

219 Cf. $R C$, pp. 182-187 193-195. 
soy casada y en ninguna manera, siendo mi esposo vivo, puedo casarme con otro. Yo no os dejo por ningún hombre de la tierra, sino por uno del cielo, que es Jesucristo, Dios y hombre verdadero: él es mi esposo [...]. Habiéndole de escoger en el cielo, ¿quién como Dios? [...] No habrá muerte, promesa o amenaza que me aparte del crucificado esposo mío"220.

Dice un demonio: "Pon al conjuro pausa, / [...] porque un pecho cristiano, que se arrima / a Cristo, en poco estima hechicerías"221. Un diálogo entre amantes: "En fe de lo que en tí he visto, / del deseo que te doma, / de adorarte no resisto, no por prenda de Mahoma, / sino por prenda de Cristo"222. "No es bien que se descompongan / con moras labios cristianos. / Por mil señales has visto / cómo yo toda soy tuya, / no por ti, sino por Cristo"223. Finalmente, este otro en que se afirma que Cristo sabe sacar bien del mal: "Caso grave, / y entre turcos jamás visto, / andar por aquí tu Cristo, / Rustán / [...]. -El suele, Mamí, sacar / de mucho mal mucho bien"224.

\section{Cervantes cristiano}

¿Se podrá seguir diciendo que Cervantes no era cristiano? ¿Que lo que a él le interesaba era la naturaleza inmanente, que nada tenía que ver con Dios, y la perfección natural de los hombres? He escrito sobre tres temas: Dios, el hombre y Jesucristo. También sobre la fe en otro estudio. La doctrina cristiana resplandece en todos ellos con numerosas citas bíblicas y con algunas de los Padres de la Iglesia. Hay otros muchos temas: la Providencia, los ángeles y los demonios, las postrimerías, la gracia, la moral, las tres leyes (natural, mosaica y evangélica), la razón y las pasiones, el gusto y lo justo, la libertad, la conciencia, las virtudes (cardinales y teologales), el pecado, los premios y los castigos, los sacramentos, la oración, las devociones, la Virgen, la Iglesia, la vida religiosa... Todos ellos están iluminados por el cristianismo. A veces, con razón, ironiza sobre algunas prácticas cristianas y sobre el clero, pero nunca ataca ni se pone al margen del cristianismo, que fluye a raudales por todos sus escritos. Cervantes no era filósofo ni teólogo, pero en sus obras hay filosofía y teología escolásticas.

JosÉ VEGA

Estudio Teológico Agustiniano

Valladolid

$220 P S, \mathrm{I}, 10,204-205$.

221 TA, II, 130.

$222 B A$, II, 299.

223 BA, III, 315.

224 GS, II, 382. 